\title{
When Does Globalization Lead to Local Adaptation? The Emergence of Hybrid Islamic Schools in Turkey, 1985-2007 ${ }^{1}$
}

\author{
Anıl Divarcı Çakmaklı \\ Istanbul Şehir University \\ Christophe Boone \\ University of Antwerp
}

Arjen van Witteloostuijn

Tilberg University

\begin{abstract}
Institutional perspectives of globalization envision the homogenization of the world through global cultural, economic, and political dynamics, while glocalization theory highlights how local cultures may adapt or resist global forces. On the basis of these theories, the authors analyze when, where, and why local hybrid organizational forms emerge as a reaction to globalization. They suggest that the impact of globalization on the emergence and expansion of hybrid organizational forms, which reflect local adaptations of global forms, depends on three types of moderators: (1) the fit between global and local ideas, values, and practices; (2) the experience of the local community with alternative organizational forms; and (3) the motivation of the local community to adapt. The authors test their hypotheses with data from the high school education system in Turkey from 1985 to 2007, a period in which Turkey experienced the growing impact of globalization.
\end{abstract}

\section{INTRODUCTION}

Globalization is often regarded as a formidable blending force, blurring boundaries between different cultures resulting in significant institutional

\footnotetext{
${ }^{1}$ The authors gratefully acknowledge financial support through the Odysseus program of the Research Foundation-Flanders (FWO). We strongly appreciate the constructive comments of the AJS reviewers. Direct correspondence to Anıl Divarcı Çakmaklı,
}

(C) 2017 by The University of Chicago. All rights reserved. 0002-9602/2017/12206-0005\$10.00 
and cultural homogenization (Robertson and Khonder 1998). Although globalization has a number of different dimensions and meanings, the diffusion of cultural models and ideas is seen as a central feature (Meyer 2000; Kern 2010). Guillén (2001, p. 236), referring to Held et al. (1999, p. 16), defines globalization as "a process fueled by, and resulting in, increasing crossborder flows of goods, money, information, and culture . . . leading to greater interdependence and mutual awareness (reflexivity) among economic, political, and social units in the world, and among actors in general." There seems to be little dispute about the fact that "in many areas of social life, common models organized in world discourse arise and penetrate social life worldwide" (Meyer 2000, p. 234). At the same time, however, a paradox emerges as this process goes hand in hand with the growing importance of the particularities of local communities in shaping local cultural adaptations (Marquis and Battilana 2009).

In line with this paradox, more recent accounts of the globalization process underscore the dialectical tension between the global and the local. Increasing global interdependence is not only a boundary-blurring force but it might also demarcate boundaries between the global and the local more sharply-for instance, when globalization represents a threat to local traditions (Marquis and Battilana 2009, p. 284). Clearly, globalization is a very complex process involving the simultaneous operation of global blending and local segregating forces. Globalization comes with a subtle interaction of tendencies toward universalism and particularism (Robertson and Khonder 1998, p. 28), produces homogenization and heterogenization (Brady, Beckfield, and Zhao 2007, p. 317), and is associated with clashes, conflicts, and tensions between Western and non-Western concepts of globalization (Robertson and Khonder 1998, p. 29). The implication is that different versions of modernity might emerge depending on the specific interplay between the global and the local.

Given that globalization is an ideology, subject to local contestation by actors and movements that make distinct claims about modernization (Guillén 2001), an important question is to understand how and when global cultural or cognitive models diffuse in local communities (Schneiberg and Clemens 2006; Marquis and Battilina 2009). There is a long tradition in institutional theory that studies the impact of higher-order institutions on lower-level outcomes (Schneiberg and Clemens 2006; Scott 2008), including how the emerging global polity affects nation-states and organizations (e.g., Meyer et al. 1997; for a review, see Schneiberg and Clemens [2006]). An understudied issue, however, is how globalization affects the local emergence of new organi-

Istanbul Şehir University, Altunizade Mh. Kuşbakışı Cd. No: 27, 34662, Istanbul, Turkey. E-mail: anildivarci@sehir.edu.tr 
zational forms or, more generally, how the coevolution of institutions and organizations affects institutional and social change (Haveman and Rao 1997, 2006; Marquis and Lounsbury 2007; Schneiberg, King, and Smith 2008). This is an important omission given that organizations are major carriers of ideology, playing an important role in the diffusion of ideas and values. Organization-building processes fuel ideological struggles and therefore are important mediators of societal change (Barnett and Woywode 2004; Simons and Ingram 2004; Haveman, Rao, and Paruchuri 2007).

We address this gap by building on globalization and institutional theory to develop an organizational ecology of the founding process of hybrid organizational forms that combine the templates and values of different parent forms. We focus on hybrid forms because most institutional change is the result of the transposition, hybridization, and recombination of materials provided by existing institutions (Djelic and Sahlin-Andersson 2006; Haveman and Rao 2006; Schneiberg and Clemens 2006). Specifically, we argue that globalization spurs the emergence of new hybrid organizational forms as a way for local communities to adjust to environmental uncertainty and episodic change (Hannan and Freeman 1989; Minkoff 2002; Haveman and Rao 2006). By combining aspects of globalization with features of local templates, hybrid organizations embody alternative institutional practices that allow actors in local communities to solve the potential tensions between the global and the local (Schneiberg and Clemens 2006). As globalization acts as a boundary-blurring force triggering (partial) institutional convergence across the globe, our baseline expectation is that globalization goes hand in hand with the emergence and expansion of such hybrid organizational forms.

However, we argue that local conditions play an important role in this process. As the word "glocal" implies, the impact of globalization depends on the interpenetration of global forces and local responses (Robertson and Khonder 1998). We follow recent developments in institutional theory that move away from envisioning the institutional environment as a geographyindependent organizational field in which mimetic processes unfold that lead to convergence (Schneiberg and Clemens 2006; Marquis and Batillana 2009). In contrast, to understand the emergence of alternative templates, multilevel models are needed that theorize about how the higher-order context interacts with local conditions in shaping multiple outcomes (Schneiberg et al. 2008; Boone and Özcan 2014). Here we claim that the extent to which globalization spurs the emergence of hybrid organizational forms will depend on specific place-bound features of local communities that affect the latter's susceptibility to adapt to processes of globalization (Marquis and Battilana 2009).

Specifically, we propose that three different types of local-level moderator conditions will block or ease the adaptation process. Thus these types of conditions will affect whether or not universalism is blended with local particularism resulting in the proliferation of specific hybrid organizational 
forms (Marquis and Battilana 2009): (1) the resonance, or lack thereof, of universal values with local traditions (local resistance; Kern 2010); (2) the (non)availability of the parent form templates in local communities (local templates; Minkoff 1994, 2002; Schneiberg and Clemens 2006; Schneiberg 2007); and (3) the absence or presence of local incentives that trigger mobilizing forces to overcome the obstacles of hybrid form emergence (local incentives; Hasenfeld and Gidron 2005).

These moderators are chosen as prior institutional research indicates that they are likely to strongly affect the susceptibility of local communities to adapt to globalization pressures. Indeed, related research on the adoption and diffusion of field-level contested innovations and institutional logics does underscore the importance of the potential adopters' incentives and cultural fit (Kennedy and Fiss 2009; Ansari, Fiss, and Zajac 2010; Fiss, Kennedy, and Davis 2012). Similarly, mainly qualitative research reveals that institutional change and the emergence of new templates are often constituted from building blocks of locally available existing institutions (Schneiberg and Clemens 2006).

Our empirical context is the Turkish high school system in the period from 1985 to 2007. Education is an appropriate setting as educational systems experience strong homogenizing pressures due to globalization (Meyer et al. 1997), which Guillén (2001, p. 244) refers to as "the worldwide spread of conformism in educational systems." Turkey is an interesting case study because there is a strong tension between the global Western version of modernism and local Islamic traditions, which is fueled by local religious polarization and secular-Islamic contestation. ${ }^{2}$ A growing number of so-called Anatolian Imam Hatip schools can be regarded as a hybrid school form because they combine the curricula of two other school forms: Anatolian and Imam Hatip high schools. The former can be identified as cosmopolitan high schools whose educational curriculum embodies secularist and Western-oriented values, while the latter are traditional religious high schools (Boone, Divarci, and van Witteloostuijn 2011). Anatolian Imam Hatip high schools are religious high schools, which also provide a Western type of education in foreign languages. Because there is considerable geographic heterogeneity in Turkey, we can study how the interplay between universalism (the extent of globalization at the national level) and different local (district-level) particularistic characteristics affects the founding rate of hybrid high schools (Anatolian Imam Hatip high schools) at the local (district) level.

\footnotetext{
${ }^{2}$ Our references to "global" and "local" do not imply that the local is without any global aspects. After all, Islam is a religion that operates globally and that has been and still is very influential in a global context. Rather, for the sake of the argument, we use "global" and "globalization" as defined in much of the literature, with reference to Western cultural, economic, and political orientations.
} 
Our key contribution is that we examine organizations as carriers of ideologies related to globalization, emphasizing their important role in how communities adapt to and affect institutional change. This important role of organizations has been underemphasized in prior work in organizational sociology (Haveman and Rao 2006). Consequently, we focus on the impact of the macrolevel globalization process on the microlevel emergence of organizational forms in a comparative context of different communities, emphasizing the role of local agency, interest, and resistance. Our study is a response to the "plea ... for a comparative sociology of globalization that is sensitive to local variations and to how agency, interest, and resistance mediate the relationship between globalization causes and outcomes" (Guillén 2001, p. 235). This research is required as we lack "theoretical perspectives that bridge the micro-macro gap, i.e., that move across levels of analysis from the world system to the nation-state, the industry, sector, community, organization, and group.... We still know little about... its consequences on such key sociological variables as organizational patterns" (p. 255).

We find considerable support for the global-local interaction hypotheses about the emergence of hybrid high schools in Turkey, which clearly underscores the saliency of recent pleas of institutional theorists that dynamic analyses of institutions and change require a focus on heterogeneity and the emergence of alternative templates (Schneiberg and Clemens 2006). Before we present our context-specific hypotheses, we first provide a rich description of the dynamics of the Turkish high school system in a country that has experienced growing religious polarization together with a rising interconnectedness with the world system.

\section{SEGREGATING AND BLENDING FORCES IN TURKEY}

\section{A Century of Religious Polarization in Turkey}

Even though the official history of Turkey as a nation-state begins with the foundation of the secular republic in 1923, with Mustafa Kemal Ataturk as its first president, the beginning of Turkish modernity can be traced back to 1839 with the start of the Tanzimat era (Kaya 2004). ${ }^{3}$ During this era, the Ottoman intelligentsia began to question the reasons behind the superiority of the West. This led to the emergence of new intellectual groups such as the Young Ottomans, who established the first constitutional regime in 1876. This era already includes the traces of the Kemalist modernization project. For example, secularism became an important topic of discussion in this period (Kaya 2004). The Tanzimat era ended in 1878. Three decades later, the

\footnotetext{
${ }^{3}$ This can be translated as the "reforms" era.
} 
Young Turks (a new group based on the ideas of the Young Ottomans) succeeded to establish the second constitutional regime by launching a military coup in 1908 and formed the first modern political party, Ittihat Terakki. Although the establishment of this second constitutional regime solved some of the problems in society, it also paved the way for a tradition of military coups in the history of the Turkish Republic (Kaya 2004). The reforms during the Tanzimat period included transformations of many institutions, including the education system. Although the transformed education system was still centered on religion, the bureaucrats of the Tanzimat era also included positive sciences in the curricula in addition to the religious courses, in order to increase the quality of education (Somel 2001).

As a military officer influenced by the Young Turks, Ataturk tried to transform the remains of the Ottoman Empire into a modern, Western-oriented state, based on secular principles with reforms that, for example, unified education, abolished the Sharia, and introduced a modern Swiss-inspired civil code after the foundation of the Turkish Republic in 1923. Gender equality was formally recognized, and women obtained the right to vote and become elected in parliament. These reforms were accompanied by several cultural and symbolic measures such as the replacement of Arabic by Latin script and the prohibition against wearing a fez. The Kemalist modernization project represented a major revolution in a basically conservative and traditional Islamic society. During the single-party era, however, there was no room for competing ideas or for any platform to express social discontent (Zürcher 2004). The interpretation of secularism in this era was not limited to the separation of the state and religion, but also involved the removal of religion from public life and control over religious institutions (Zürcher 2004). Therefore, it is no surprise that religious opposition arose from the very beginning (Zürcher 2004). In fact, the Kemalist reforms lie at the very origin of the gradual rise of political Islam in the second half of the 20th century (Sakallığlu 1996; Önis 1997; Güven 2005).

Military officers and civilian bureaucrats - the major power holders in the authoritarian state-imposed the westernization project unilaterally during the single-party era in the republic's history until 1946 (Sakallığlu 1996). Eventually, so much contention arose that the state had to allow parties other than the Republican People's Party into the political arena at the end of World War II. The importance of the opposition is demonstrated by the huge victory of the center-right Democratic Party (DP), which gained $53.4 \%$ of the votes in the 1950 elections - a party that claimed to represent the periphery against the secular, bureaucratic intelligentsia. One of the first actions of the new government was to relax the dominance of secularism that had been a feature of the single-party era (Zürcher 2004). The government introduced voluntary religious courses into primary schools, restored 
the Arabic instead of the Turkish call to prayer, and established Imam Hatip (i.e., preacher) schools and a faculty of divinity at Ankara University. For the secularists who had internalized Kemalist principles - such as civil servants, academics, and military officers - this relaxation was a threat to their cultural and political hegemony (Zürcher 2004).

The DP government ended in 1960 with a military coup. The Turkish army has always considered itself the guardian of Kemalist principles and was uncomfortable with the DP's policies. The DP was closed down and banned from politics. After the army handed over power to a newly elected government in 1961, a period of liberalization followed. The 1960s were a decade in which ideologies clashed and became a matter of public debate (Landau 1997). In 1970, the National Order Party (NOP), the first pro-Islamic party of the Turkish Republic, was founded. Even though NOP's party program emphasized democratic values, the party firmly stood for freedom of religion and Islamic education. As the party also rejected any type of secularism that could be perceived as being hostile toward Islam (Landau 1997), it offered a voice to religious and conservative people (Güven 2005). However, the NOP was banned in 1971 because it violated the secularist principles of the Turkish Constitution. The role of religion in public life was not the only source of polarization in Turkey during the 1970s. Economic recessions led to social unrest, and different factions at both the extreme left and right emerged to fight for the control of the streets and campuses (Zürcher 2004). To end this state of chaos, the military took over again in 1971.

After the military intervention of 1971 , successive governments failed to solve Turkey's economic and political problems. Many political parties and social movements emerged representing various ideologies, ranging from extreme left to extreme right, including religious sects and Kurdish separatists. Most of these groups strongly opposed the repressive Kemalist ideology. These developments expanded the boundaries of pluralism in Turkish society and generated polarization along ideological lines. The end result was escalating violence and a new military coup in 1980 (Pak 2004). Although one of the aims of the military leaders of the 1980 coup was to defend the Kemalist principles, this time the underlying motivation was quite different. The leaders "defined the causes of the socio-political problems as a lack of religious dignity and the domination of a left-wing discourse in society" (Güven 2005, p. 198). They realized that the Kemalist ideology did not resonate well among the majority of the Turkish population and that religion could be used as a unifying power against the fragmentation and contestation caused by the rise of leftists, socialists, radical religious sects, ultranationalists, and Kurdish separatists (Ahmad 1991; Salt 1995; Pak 2004). The aim was to create a more homogeneous and less political Islamic community (Yavuz 1997). Consequently, the military government made tactical concessions to religious interests not only to secure their support but also to 
gain official control over religious issues, including the role of religion in education.

This action contributed to the rise of political Islam and the development of a new ideological concept, the "Turkish Islamic synthesis," which was constructed by a group of conservative scholars (Yavuz 1997; Güven 2005). This ideology, supported by the center-right Motherland Party representing a diverse electorate, attempted to assimilate Islamic groups and nationalists. The aim was to integrate Islamic symbols with nationalism and, by so doing, to create a more homogeneous and less political Islamic society and to avoid the influence of left-wing ideologies (Rabasa and Larrabee 2008). The influence of religion in public life strongly increased as a result of these developments. The rise of political Islam eventually culminated in the victory of the Islamic Welfare Party in the 1995 elections and the appointment of the first Islamic prime minister (Necmettin Erbakan) of the Turkish Republic. The result of the election "revealed a society sharply divided along secular versus Islamist sociocultural lines" (Yavuz 1997, p. 63).

Since the 1990s, the relationship between politics and religion has become an increasingly important issue in Turkish society as a result of the rise of Islam—politically, economically, and culturally (Keyman 2007). Politically, religion became politicized through the rise to power of Islam-inspired political parties. Economically, "Anatolian tigers" emerged, as witnessed by the foundation of MUSIAD (Independent Industrialists' and Businessmen's Association), a business association of religiously conservative businessmen from Anatolia that aims to combine free-market practices and traditional religious values. ${ }^{4}$ Culturally, the demands of the religious sects increased, symbolized by the plea to have headscarves accepted in public organizations or at the universities (Keyman 2007). However, the growing antisecular rhetoric and activities of those in power disappointed and agitated secular public opinion. This resulted in an escalation of the tension and antagonism between both factions (Heper and Güney 2000; Güven 2005). For secularists, defying Kemalist principles is a threat for democracy, culture, and the republic, while the Islamic opposition wants to "de-Kemalize" culture and in order to obtain freedom of expression of religion in public life (Aydın and Çolak 2004). The politicization of Islam, in turn, further triggered the fear of secularists about the manifestation of religion in public life (Aydın and Çolak 2004). This is demonstrated by the establishment of several movement and countermovement organizations in this era, leading to increasing polarization, dividing Turkey into two dominant factions (underpinned by many smaller ones) that are clearly distinct: a secular and a religious one.

\footnotetext{
${ }^{4}$ The term "Anatolian tigers" refers to a number of cities in Turkey that have displayed impressive growth since the 1980s.
} 
The Blending Force of Globalization in Turkey

Ever since the foundation of the Turkish Republic, the country has been going through economic and social changes that originally took root in the westernization movement of Ottoman society in the 19th century. However, these changes have brought along their own internal conflicts (Çarkoğlu and Toprak 2007). Specifically, this process of change created conflict between the supporters of Western-style modernization and the countermovements reacting against such westernization. Moreover, even though Turkish modernization has been a project of the state since the foundation of the Turkish Republic, the integration of the Turkish economy into the global marketplace began only in the 1980s with economic liberalization (Keyman and Koyuncu 2005).

Turgut Ozal, the nineteenth prime minister of Turkey and one of the architects of the Turkish Islamic synthesis, introduced a series of transformative policies paving the way for economic liberalization, as well as the reestablishment of parliamentary democracy after the 1980 military coup. The aim of the economic policies of this period was to shift from a protectionist and import-substitution approach to a liberal and market-oriented strategy instead (Harrison, Rutherford, and Tarr 1993). The reason behind this radical shift was the fact that the Turkish economy had been suffering from structural constraints to growth for some years. The solution introduced by the liberal government was the integration of the Turkish economy into the world capitalist system (Ardiç 2009). This integration process was not only initiated by government policies but also stimulated through structural adjustment programs organized by the International Monetary Fund and the World Bank (Cizre and Yeldan 2005). As a result of the liberalization policies, Turkey developed economic relationships with several countries and gained access to a range of export markets. However, rapid economic development required large capital imports because domestic savings were insufficient for the required investment. In this period, foreign investors were attracted by Turkey's great economic potential and increasingly liberal economic policies; as a result, the amount of foreign capital invested in Turkey increased rapidly (Ardıç 2009).

The globalization process that took off with Turkey's integration into global capitalism also had political and social consequences. First, the economic international relations of Turkey improved through increasing trade and foreign direct investment. Second, as a consequence of economic development and advanced communication technologies, global connectivity and global consciousness increased. The most prominent reflections of global culture in Turkey can be seen in the patterns of consumption and in the lifestyle of its inhabitants (Helvacioglu 2000). The global cultural ideas and practices began to spread by means of mass media. Globalization acted as a blend- 
ing force by blurring the distinctions between Turkey and the rest of the world, increasing the interconnectedness of the country with global norms, values, and practices.

The impact of globalization on the Turkish society is illustrated in figure 1, which plots the KOF (Konjunkturforschungsstelle) globalization index for Turkey for the period 1970-2007 (on a scale of 1-100 each year, with higher numbers indicating more globalization). This index was first presented in 2002 (Dreher 2006) and measures the extent of globalization of a country along three dimensions: economic, political, and social. It is well suited for our purpose as it closely matches recent definitions of globalization, that is, the extent of global interconnectedness of a country among economic, political, and social units (Guillén 2001). Subsequent empirical work has shown that the KOF index is a valid measure of a country's extent of globalization (see the methods section for a discussion). The KOF index covers 123 countries and includes 23 variables, underscoring the fact that globalization is a multifaceted concept. The data were obtained from the website of the Swiss Economic Institute (http://www.kof.ethz.ch/).

Figure 1 illustrates that globalization started to accelerate in Turkey around 1985 (see also Cizre and Yeldan 2005). All KOF indices rapidly increased until 1994 and subsequently continued to grow incrementally until the end of the period, by and large, revealing the influential impact of the globalization wave.

The rise of political Islam together with increasing globalization and the implementation of neoliberal policies led to the emergence of an alternative, non-Western modernity - a religious/modern synthesis - espoused by the socalled new "devout bourgeois class" (Demir, Acar, and Toprak 2004). As a consequence of neoliberal economic policies starting in the "Ozal period," many religiously conservative cities, such as Denizli, Konya, and Kayseri, ex-

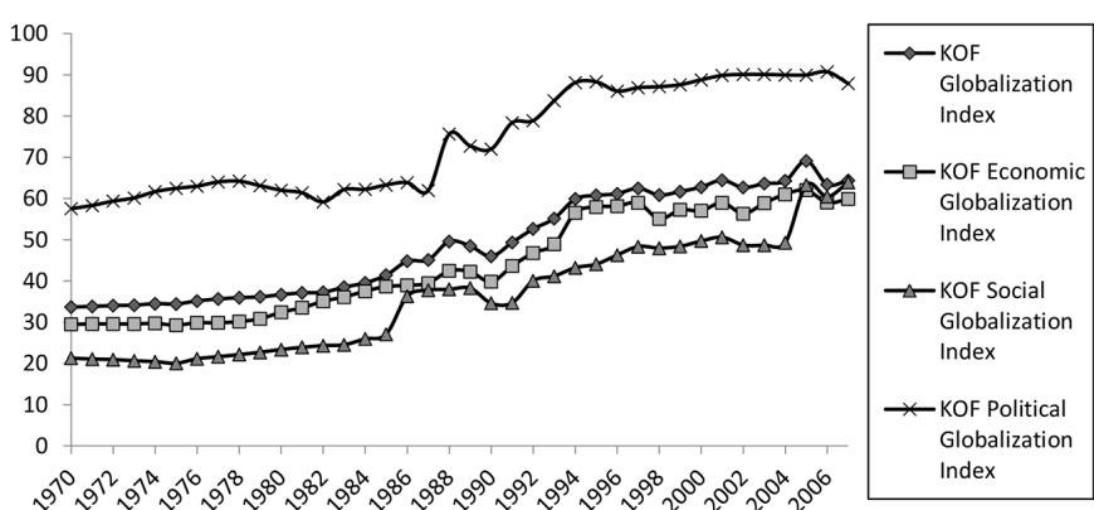

FIG. 1.-KOF globalization index and its three dimensions for Turkey, 1970-2007 
perienced rapid economic growth and development. By improving their business practices, small and medium-sized enterprises in those cities prospered and formed new business communities (Demir et al. 2004). Economic liberalization strongly increased economic productivity and capital accumulation in Anatolia. The emergence of the Anatolian tigers contributed to the wealth of the relatively religious and conservative faction that resides in Anatolia.

These developments made it clear to more conservative and religious people that globalization, economic growth, and Islam are not necessarily contradictory, but can be synthesized instead (Özbudun and Keyman 2002). Indeed, the religious faction started to criticize "the status of the secularrational thinking as the exclusive source of modernity in Turkey" (Keyman and Koyuncu 2005, p. 110). The devout bourgeois class used modern methods of business and demanded more political freedom yet wanted to realize this without losing its religious identity (Demir et al. 2004). The emergence of this new class was also reflected institutionally in the emergence of new school forms, business associations, and social movements. Some of the prominent examples are the diffusion of Islamic banks (interest-free banking) and the emergence of MUSIAD. These developments fueled the tension between the secular elites, who embraced Western modernity, and the new rising elite class striving for a religious/modern synthesis.

\section{Implications for the Turkish High School System}

Given that high schools are the cradle for future elites, religious contention and the rising tension between different forms of modernism had an enormous impact on the dynamics of the Turkish high school system. As education is an extremely important vehicle for the diffusion of values and ideologies in societies (Nielsen and Hannan 1977), the educational system was and remains a major battlefield (see Güven 2005), where all these tensions materialize via the establishment of different school types that carry these different ideologies.

Traditionally, there are three types of high schools that prepare students for higher education in Turkey: regular high schools, Anatolian high schools (both secular), and Imam Hatip high schools. ${ }^{5}$ Regular high schools are the dominant type in Turkey. These are the basic high schools that do not require any entrance exam. Anatolian high schools admit their students on the basis of the nationwide high school entrance score, and they provide education in foreign languages. In addition, Anatolian high schools provide higher-

\footnotetext{
${ }^{5}$ There are also private high schools in Turkey. However, in this article, we focus on the public high schools that do not require any tuition. Private schools constituted a meager $1 \%$ of all high schools in Turkey as of 2007 (National Education Statistics, published by the Turkish Ministry of National Education).
} 
quality education than the other two types, and their curriculum embodies secularist and Western-oriented values. The first Anatolian high schools were established by the government in 1955 as alternatives to international (e.g., French, German, or Italian) high schools that provided high-quality and foreign language education in Turkey. ${ }^{6}$ In the meantime, as the impact of globalization intensified, these schools became more and more popular among the secular faction mainly because these schools do not force any type of religion on the students and at the same time provide high-quality education including foreign languages - both seen as a first step for a student to become connected to the rest of the world.

On the other side of the ideological spectrum, Imam Hatip high schools provide religious education. Although the aim of Ataturk was to provide one unified, secular educational system, one of the major strategies of the Islamic movement was the creation of a counterelite by gradually strengthening the Islamic stream in the educational system (Güven 2005). ${ }^{7}$ As a result, during the 20th century, the number of Imam Hatip high schools expanded so much that duality in education became a fact (Güven 2005). Depending on the ruling government's views, the Imam Hatip schools went through several changes over time. While some governments saw them as a threat to secularism and therefore took measures to weaken them, others viewed them as a tool to stimulate Islamic discourse and hence took measures to develop them further (Özgür 2012). Even though Imam Hatip high schools were originally founded to educate imams and preachers, because of the resurgence of Islam during the 1950s and after a series of regulatory changes (Pak 2004), Imam Hatip high schools have become regular educational institutions, preparing students for higher education. ${ }^{8}$

The main characteristic of Imam Hatip high schools is that they provide vocational courses as well as standard arts and science classes. Secularists perceived the expansion of both the mission and number of Imam Hatip

\footnotetext{
${ }^{6}$ The state was suspicious that students of foreign schools would be influenced too much by foreign values and would be insufficiently aware of their own history and culture. Therefore, the Turkish state decided to establish its own cosmopolitan schools.

${ }^{7}$ Ataturk's aim was to keep religion and religious activities under the control of the secular state; this strategy also extended to the educational system. The Ottoman Empire had a multiplicity of schools, which all had a religious component in their curriculum (Somel 2001). After the foundation of the Turkish Republic, with the Unification of Education Law in 1924, all educational institutions in Turkey became controlled by the state (Özgür 2012).

${ }^{8}$ The roots of Imam Hatip high schools can be traced back to the madrassas in the Ottoman Empire. Many of the madrassas also went through transformations, particularly during the late Ottoman period, because of the erosion of their qualities and increasing relations with the West. In this sense, already in the Ottoman Empire Imam Hatip high schools had hybrid features combining religious education with regular Western-oriented high school education.
} 
high schools as a threat, because a growing number of young people were not educated to become an imam or a preacher, but instead "potential agents of Islamic traditionalism and a potential source of votes for traditionalfundamentalist politicians" (Sezer 1993, pp. 23-24). Indeed, the graduates of Imam Hatip high schools gradually entered elite functions in many sectors of Turkish society (Dorian 1997). As might be expected, Imam Hatip high schools are popular among religious parents who want their children to be religiously educated in addition to receiving standard schooling, while Anatolian high schools are preferred by parents who want their children to be educated in line with secular/cosmopolitan norms (Pak 2004).

In 1985, a new school form emerged in the Turkish education system: Anatolian Imam Hatip high schools - a combination of the curriculum of the Anatolian high schools with that of the Imam Hatip-inspired religious education (Pak 2004). As a result, Anatolian Imam Hatip high schools can be seen as a hybrid school form. The Imam Hatip high schools include substantial religious education in addition to the standard arts and science classes while they provide scant English-language training. For the newly emerged devout bourgeois class, the question was which type of education they wanted their children to have. Because of the intensification of globalization, Imam Hatip high schools lost their attractiveness to religious parents because these schools could not accommodate the upcoming global values, norms, and practices. The new hybrid high school form offered a solution by including religious education along with the high-quality foreign language education essential in allowing their graduates to connect with the rest of the world. Yet, unlike Anatolian high schools, the curriculum of Anatolian Imam Hatip high schools includes courses such as Arabic, theology, and holy Qur'an as well as standard courses like mathematics and natural sciences (Turkish Ministry of Education, General Directorate of Religious Education). In parallel to the changes in the world and in Turkish society, conservative and religious parents preferred their children be educated in modern schools that taught foreign languages, had computer labs, and offered sports facilities (Gökaçtı 2005). For these parents, having their children learn to speak at least one foreign language, acquire the knowledge necessary to use up-to-date technology, and become aware of what is going on in the world were important, next to religious knowledge (Gökaçtı 2005).

Together with the intensification of the impact of globalization, the number of Anatolian Imam Hatip high schools increased rapidly. Figures 2 and 3 provide the relative densities of the different school forms. As can be seen from the figures, the dominant high school type in Turkey is the regular high school. In $2007,55 \%$ of all public high schools were regular high schools, but this percentage had dropped dramatically from $72 \%$ in 1985 . In the expanding periphery of the regular high school system, the prominent school types include Anatolian (5\% in 1985 and $25 \%$ in 2007), Imam Hatip (23\% in 


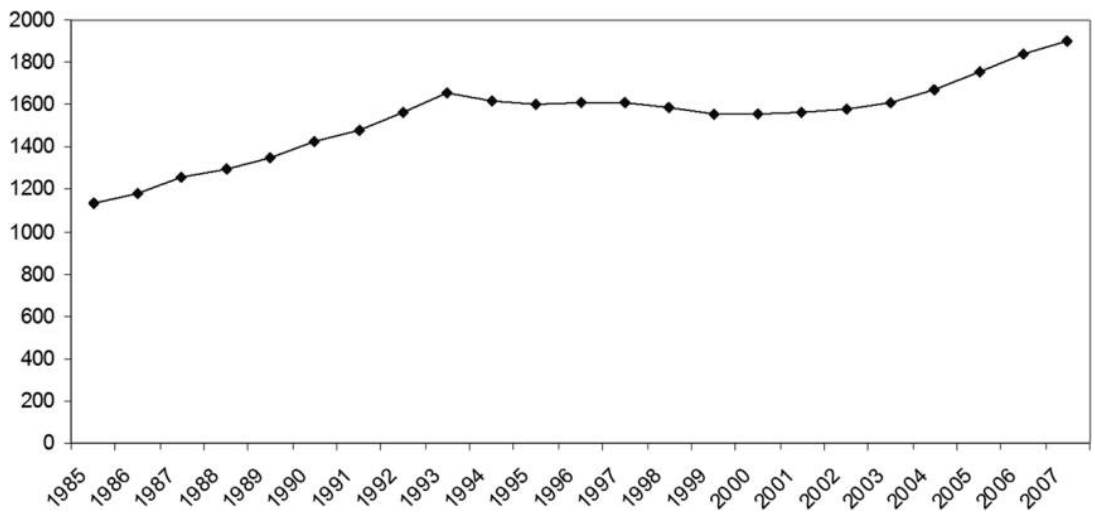

FIG. 2.- The density of regular high schools, 1985-2007

1985 and 14\% in 2007), and Anatolian Imam Hatip high schools (only one school in 1985 and 6\% in 2007). The relative importance of both Anatolian and Anatolian Imam Hatip high schools substantially increased over time (also demonstrated by their growing densities; see fig. 2), at the expense of the dominant regular high schools and the traditional Imam Hatip high schools (for which growth seems to stagnate). Figure 3 exhibits the growing popularity of Anatolian Imam Hatip high schools among the religious faction.

What makes the Turkish high school system highly appropriate for our purposes is that the growth of the density of Anatolian Imam Hatip high schools varies widely across localities in Turkey, defined as districts. Hence, below, we develop hypotheses that may explain this geographical variation, both in and over time. That is, we formulate hypotheses specific for the Turk-

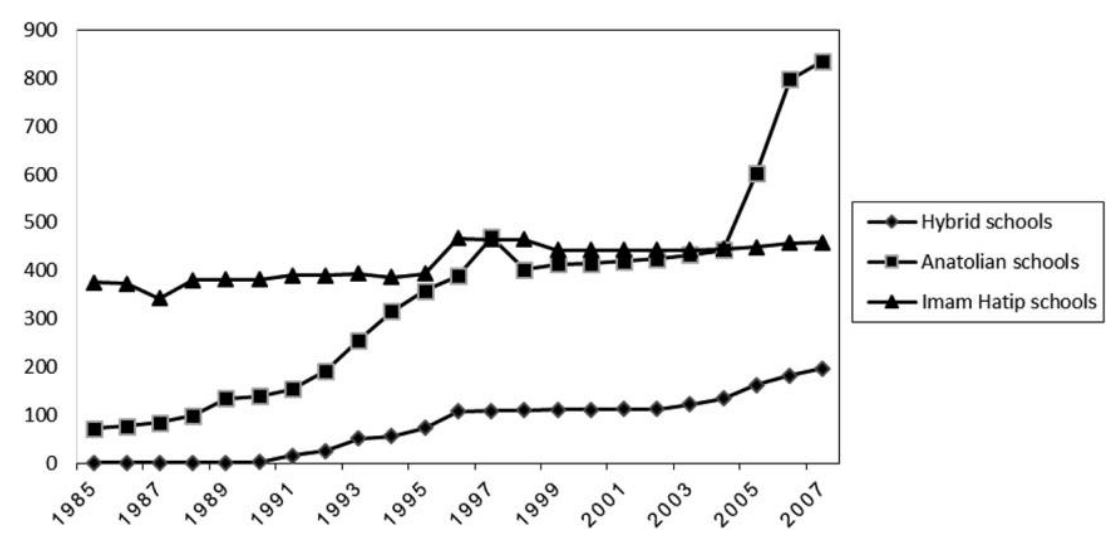

FIG. 3.- The density of Imam Hatip, Anatolian, and hybrid high schools, 1985-2007 
American Journal of Sociology

ish high school context, focusing on the district-level founding rate of hybrid Anatolian Imam Hatip high schools as our dependent variable.

\section{THE EMERGENCE OF HYBRID HIGH SCHOOLS}

\section{Globalization Push}

The boundaries of different organizational forms are determined by the balance between segregating and blending mechanisms because continuity among organizational populations depends on the relative strength of both opposing forces (Hannan and Freeman 1989, p. 60). While segregating mechanisms separate organizations into distinct forms by reifying differences, blending mechanisms blur distinctions between organizational forms by reifying similarities (Hannan and Freeman 1989; Haveman and Rao 2006). If blending mechanisms are strong, distinctions among forms are relatively arbitrary and easily bridged. Thus, opportunities for hybrid organizational forms are created that combine the institutional logic materialized in two or more organizational forms (Hannan and Freeman 1989; Haveman and Rao 2006).

According to institutional theory, globalization acts as a blending force by spreading cosmopolitan values, practices, and institutions through isomorphic processes (Meyer et al. 1997; Boli and Thomas 1999; Schneiberg and Clemens 2006). States derive much of their structure and authority from being embedded in a global world, which consists of common legitimating models. Meyer et al. (1997, p. 169) argued that "instead of a central actor, the culture of world society allocates responsible and authoritative actorhood to nation-states." Therefore, globalization provides the necessary templates for nation-states and hence affects the evolution of organizational forms. Following this argument, we propose that globalization spurs local communities to adapt by adopting hybrid organizational forms.

Despite the pressure for global convergence of education systems (Meyer and Hannan 1979; Meyer, Bromley, and Ramirez 2010), schools are still one of the most important vehicles for nation building and the reproduction of national ideologies (Nielsen and Hannan 1977; Saito 2011). Subsequently, nation-states face a dilemma in terms of which institutional logic to adopt, that is, the global or the local. The resolution for this contradiction often resides in adapting the existing institutional arrangements by blending different institutional logics (Marquis and Battilana 2009). One way is to adopt particular features from the global organizational form and to blend these with the existing local ones. By building hybrid school forms, local communities avoid radical institutional change and gradually adapt to the globalization of the school system (Haveman and Rao 2006; Saito 2011).

In the slipstream of Turkey's accelerating integration in the global market economy in the 1980s (Cizre and Yeldan 2005), global norms, values, and 
practices began to spread to all spheres of life, including the education system (Meyer et al. 1997). As a result of these developments, the traditional education provided by Imam Hatip high schools began to fall short. Particularly, the newly emerging devout bourgeois class realized that education not only serves to diffuse and strengthen religious norms but should also prepare their children to acquire the necessary competencies and skills to become world citizens (Saito 2011). In order to be part of the future elite in a globalizing world, standard education combined with religious education does not suffice anymore as the oppositional secular elite enjoins high-quality education — adapted to globalization practices - at Anatolian high schools.

These developments increased demand for hybrid schooling in Turkey (high-quality cosmopolitan education embedded in Islamic traditions) and triggered the establishment of Anatolian Imam Hatip high schools. This demand is met in two ways. First, the Turkish Ministry of Education, which is responsible for top-down decisions about the location, number, and type of high schools to be established in the different districts, takes into account the needs of local communities. Second, bottom-up, the local community can request a certain type of school in their district by making a demand to the corresponding governor, who in turn transmits this request to the Ministry of Education. Moreover, if the local community donates the necessary buildings and equipment to the state for a new school, then the government gives permission for the founding of the school and assigns teaching staff. As a result, the founding process of high schools in Turkey is both a top-down and a bottom-up process, implying that both local conditions and local collective actions are important drivers of new school formation. ${ }^{9}$

Нуротнеsis 1.-The district-level founding rate of hybrid high schools (Anatolian Imam Hatip high schools) increases with globalization.

\section{Local Resistance}

The globalization process in Turkey takes place in a society that historically has strong traditional and conservative Islamic roots. The perception and practice of religion, however, are not homogeneously distributed across Turkey. In some regions, the devout bourgeoisie became an important new social class (e.g., in Anatolia); in other regions, there are still many Islamic factions that strongly oppose Western-type modernity. These cultural and ideological differences between localities affect how people react to forces of globalization and, hence, the extent to which hybrid school forms will emerge (Marquis and Battilana 2009). Kern (2010) argues that adaptation to global practices requires cultural resonance. Then global institutions, values, and norms

\footnotetext{
${ }^{9}$ For the principles of school foundings, we refer to http://www.meb.gov.tr/duyurular /duyurular2010/mub/kurum_acilmasina_iliskin_esaslar.pdf.
} 
are regarded as persuasive ideas because they are compatible with existing ones or provide answers and solutions to individual problems and will be translated to fit locally available principles and practices (Gamson 1992; Campbell 2004; Kern 2010).

However, when globalization represents a threat to local traditions, it may demarcate boundaries between the global and the local more sharply (Marquis and Battilana 2009, p. 284). Then westernization clashes with the local, triggering resistance and spurring ideological contestation and segregation. In the present context, in districts where Islamic traditionalism has a strong foothold (as witnessed by voting for the most religious parties), ${ }^{10}$ resistance against globalization has traditionally been very high. It can therefore be predicted that in these districts demand for hybrid education will be extremely low even with strong globalization pressure. When religious traditionalism is low, in contrast, people will welcome hybrid solutions as a response to globalization.

This reasoning is consistent with research in other settings that show that ideological clashes have had a profound impact on the dynamics of several industries (Boone and Özcan 2014). For instance, anticorporate movements in the United States, which defend the community logic against mass-market consolidation, have prevented the opening of Wal-Mart stores in some communities (Ingram and Rao 2004; Rao, Yue, and Ingram 2011). In a similar vein, local cultural resistance hampered the growth of mass-market commercial banks in the United States in the 20th century (Marquis and Lounsbury 2007; Marquis and Huang 2009). Apparently, communities seem to adopt dominant institutional templates only when cultural resistance is low. Taken together, we therefore expect that the proportion of votes on the most religious parties will negatively moderate the impact of globalization on the emergence of Anatolian Imam Hatip high schools.

Нуротнеsis 2.-The positive impact of globalization on the district-level founding rate of hybrid high schools (Anatolian Imam Hatip high schools) decreases with the proportion of votes on the most religious parties in a local community.

\section{Local Templates}

Anatolian Imam Hatip high schools not only blend the curricula of Imam Hatip and Anatolian high schools into hybrid education but also blend their names literally as Anatolian Imam Hatip high schools. In districts in which both parent forms are firmly established, local people will not be unfamiliar with the recombination implied by the newly emerging hybrid form. Ac-

${ }^{10}$ The "most religious parties" category does not refer to militant Islamist groups, but instead to the legal political parties that voice a religious rhetoric. 
cording to institutional theory, the presence of both parent forms in a district should facilitate institutional recombination, and hence the emergence of hybrid high schools, for two main reasons (Oliver and Montgomery 2000; Minkoff 2002; Haveman and Rao 2006; Schneiberg and Clemens 2006; Schneiberg 2007).

First, the presence of parent form high schools in a local district provides the necessary variation in organizational templates for hybrid organizational forms to emerge (Minkoff 2002; Haveman and Rao 2006). Organizational variation is the raw material for institutional recombination, which is the main feature of hybrid forms. In a similar vein, established institutional paths represent the stock of resources and opportunities in local communities for transformation and for the development of alternative organizational forms (Schneiberg 2007). For instance, experience with different organizational forms in local communities is a resource for institutional recombination or redeployment. Existing organizational forms constrain and enable mobilization and shape the capacity of new organizational forms to produce change (Schneiberg and Lounsbury 2008).

Second, as hybrid forms blend population boundaries, they face obstacles to build up legitimacy and obtain resources (Minkoff 2002). However, newly emerging organizational forms tend to benefit from the legitimacy of established organizations if they fall into a cognitive category that is easily recognizable by the relevant audiences (Dobrev, Özdemir, and Teo 2006). In this sense, the relationship between established and newly emerging organizational forms, which are differentiated by some aspects in comparison to the established forms, as is the case for hybrid organizational forms, may be mutualistic (Dobrev et al. 2006). Because of such legitimation spillovers, we therefore expect that the local hybrid school founding rate will increase with globalization especially when the local prevalence (i.e., density) of both parent forms is high (i.e., Imam Hatip high schools and Anatolian high schools; Minkoff 1994, 2002), suggesting an interaction of local templates with globalization. That is, the positive impact of globalization is amplified in a community with higher densities of both parent forms.

Нуротнеsis 3.- The positive impact of globalization on the district-level founding rate of hybrid high schools (Anatolian Imam Hatip high schools) increases with the density of both parent schoolforms (Anatolian high schools and Imam Hatip high schools) in a local community.

\section{Local Incentives}

Organizations that conform to established categories are easier for audiences to recognize and to identify with, enhancing their legitimacy (Hannan and Freeman 1989; Hannan, Pólos, and Carroll 2007). Because hybrid organizations blur the boundaries of taken-for-granted organizational forms, bound- 
ary spanning generally meets sharp punishment as it has low appeal among audiences (Rao, Monin, and Durand 2005; Hsu, Hannan, and Koçak 2009; Hannan 2010; Kovács and Hannan 2010). Particularly, the punishment gets stronger if the category codes are oppositional or involve moral imperatives (Kovács and Hannan 2010). In this sense, building hybrid organizational forms and marshaling their acceptance require strong motivation of actors in order to gain local commitment and mobilize the necessary resources (Benson 1977). We argue that two types of incentives may serve as mobilizing motivational forces: economic and ideological incentives (Boone and Özcan 2014).

First, local communities are more likely to adjust to globalization when economic incentives to do so are high. Particularly, we claim that the degree of resonance between global and local norms, values, and practices will be high when the local community has a strong entrepreneurial culture, as witnessed by the growth in the number of entrepreneurs. We predict that globalization will spur the adoption of alternative modernities - that unify Islamic traditions with features of Western modernism as reflected in hybrid schools - in entrepreneurial districts. Being part of a global world (economic) system is instrumental for entrepreneurs as a precondition for the accumulation of capital and wealth. Local entrepreneurs have to operate in a marketplace that is modeled along the lines of practices spread through economic globalization. They are therefore likely to bridge the gap between the local and global world of economic capitalism.

By the nature of their role, entrepreneurs are economically motivated. They run a business that has to make a profit to be sustainable (Kirzner 1997). As Shane and Venkataraman (2000) point out, opportunity recognition is a key attribute of entrepreneurship. And after an entrepreneur has observed an opportunity for a profitable business, she or he will seek to reap this opportunity (Eckhardt and Shane 2003). In the context of globalization, we argue that local entrepreneurs spot business opportunities resulting from being linked to this global economic world and hence seek to promote the development of conditions and competencies required to capture these opportunities. From this perspective, religious entrepreneurial communities can benefit greatly from Anatolian Imam Hatip high schools, which teach the knowledge and skills required for operating in the global business world-an illustrative example being proficiency in English, the world's lingua franca.

Нуротнеsis 4.- The positive impact of globalization on the district-level founding rate of hybrid high schools (Anatolian Imam Hatip high schools) increases with the growth of the number of entrepreneurs in a local community.

Second, ideological polarization is another mobilizing force (Kurzman 1998; Hasenfeld and Gidron 2005; Boone and Özcan 2014), because rivalry between dissimilar ideologies makes ideologies extremely sharp and salient, which mobilizes the adherents of these ideologies to diffuse their values and 
preferences (Olzak and West 1991; Barnett and Woywode 2004; Simons and Ingram 2004). This is consistent with Meyer and Staggenborg's (1996, p. 1638) proposition that "when movements effectively create or exploit events, they are likely to encourage countermovement mobilization at the same time that they advance their own causes." The salience argument contends that ideological rivalry "galvanizes" the opposing groups and so spurs the formation of formal organizations that carry these ideological values (Olzak and West, 1991, p. 459). Such organization building mobilizes even more collective action (Tilly 1978) such that the establishment of one organizational form will reinforce the dynamics of the rival one (Boone et al. 2011).

As carriers of ideologies, schools are affected by the distribution of different ideologies in society. Each subgroup representing these ideologies demands a specific form of schooling that fits with its ideology. In addition, schools have strategic importance for decision makers, since education is a state instrument to influence the relationship of the individual to the state or polity (Nielsen and Hannan 1977). So the demand for and supply of specific types of schooling are driven by the prevailing ideologies in society and private actors trying to influence political elites via social movements in order to obtain schooling that fits with their ideology (Meyer and Staggenborg 1996; Güven 2005).

In Turkey, the century-long ideological/religious polarization mobilized the participants of each faction to create structural arrangements against each other in order to compete (Benson 1977). The number of Imam Hatip high schools increased particularly in the 1950s in Turkey because of the increasing influence of political Islam. At the same time, this triggered action from secular countermovements with a strong demand for educational expansion of the secular/cosmopolitan high school type (Heper and Güney 2000; Güven 2005). Therefore, both forms stimulated each other's growth rate as a result of a sequence of movements and countermovements (Boone et al. 2011).

With the emergence of a devout bourgeois class, cosmopolitan education gained strategic importance for the religious population as well. In order to be connected with the rest of the world and to be a part of the elite as a global actor (Meyer 2000), religious education had to compete on similar grounds with the secular/cosmopolitan high schools by establishing hybrid school forms. So, with the increasing impact of globalization, the nature of competition between secular and religious factions gained a new dimension: the need to adapt to global norms, values, and practices. Ideological/religious polarization acts as a mobilizing force for the religious faction to reach out for an alternative structural arrangement - that is, the establishment of hybrid high schools - to be able to compete with the secular faction for elite functions (Hasenfeld and Gidron 2005). Therefore, we expect that the motiva- 


\section{American Journal of Sociology}

tion of the religious faction to blend religious and cosmopolitan identities as a response to globalization will be more pronounced when local polarization/ideological contention in the district is high.

Нуротнеsis 5.-The positive impact of globalization on the district-level founding rate of hybrid high schools (Anatolian Imam Hatip high schools) increases with religious-secular polarization in a local community.

\section{DATA AND METHODS}

Data

The data set covers the period from 1985 to 2007 for 81 districts in Turkey. We counted the annual number of Anatolian, Imam Hatip, and Anatolian Imam Hatip high schools in Turkey at the district level. We start our analysis with the foundation of the first Anatolian Imam Hatip school in 1985 and end our analysis in 2007 because a new regulation in 2008 transformed all regular high schools into Anatolian high schools. ${ }^{11}$ The data for Imam Hatip high schools and Anatolian high schools were obtained from National Education Statistics, as published by the Prime Ministry State Institute of Statistics. The data for Anatolian Imam Hatip high schools were collected through the high school directory and the websites of each Anatolian Imam Hatip high school.

\section{Dependent Variable}

Following the organizational ecology literature, our dependent variable is the annual founding rate of Anatolian Imam Hatip high schools at the district level (yearly number of new entries into the local district-level population). Note that, given that we do not observe any exit or mortality of hybrid Anatolian Imam Hatip high schools, our yearly founding count is in fact a first-difference variable of hybrid high school density at time $t$ minus this density at time $t-1$.

\section{Independent Variables}

Depending on the specific definition of globalization, the literature emphasizes different ways to measure globalization and its different dimensions. Some emphasize the economic angle (Harvey 1989; Sassen 1991), others focus on the political dimension (McGrew 1997; Held 1998), and yet others claim that the economic and political perspectives ignore the cultural as-

\footnotetext{
${ }^{11}$ The curriculum of regular schools has changed, and the weight of foreign language
} courses has increased. 
pects of globalization (Ritzer 1993). Guillén (2001) provides a detailed analysis of different perspectives regarding globalization and its indicators. He classifies these indicators into economic, financial, social/political, and bibliographical measures, and he argues that globalization should best be regarded as a multifaceted concept that cannot be captured by a single variable. Therefore, in the current study, we decided to employ the KOF index of globalization, which explicitly accounts for the multidimensional nature of globalization.

The KOF index represents an attempt to develop a broad measure of the extent of globalization of a country. This index has been accepted in recent empirical literature as a valid measure and was first presented in 2002, covering 123 countries and including 23 variables (Dreher 2006). The index includes economic, political, and social dimensions of globalization. Each of these three dimensions is further divided into subdimensions. Economic globalization of a country is described by actual economic flows (trade, foreign direct investment, portfolio investment, and income payments to foreign nationals, each measured as a percentage of GDP) and the absence of restrictions (hidden import barriers, mean tariff rate, taxes on international trade, and capital account restrictions). Political globalization is measured with the number of foreign embassies, memberships of international organizations, and participation in the UN Security Council missions. Social globalization covers items such as international tourism, number of internet hosts and users, as well as the number of McDonald's restaurants and IKEA shops (per capita). The annually updated KOF index measures globalization on a scale from 1 to 100, with higher numbers indicating more globalization. The data were obtained from the website of the Swiss Economic Institute.

A number of studies employ the KOF index of globalization. Bergh and Nilsson (2010) examine the relationship between the KOF index of globalization and income inequality by using panel data covering about 80 countries for the period 1970-2005. Chang, Lee, and Hsieh (2011) analyze the longrun relationship between real output and the $\mathrm{KOF}$ index of globalization by employing annual data of Group of 7 countries from 1970 to 2006. Potrafke (2010) investigates the influence of globalization on a variety of aspects of labor market deregulation by taking the KOF index as a proxy of globalization for 20 OECD countries in the 1982-2003 period. Using panel data of 39 countries over the period 1979-2007, Chang and Lee (2012) estimate the impact of the KOF index of globalization on the development and convergence of international life insurance markets. The aim of Pekarskiene and Susniene (2011) is to assess the (changes in the) level of globalization in the Baltic countries using the KOF globalization index.

As a further validity check, we collected data regarding the number of nonprofit international organizations that have headquarters in Turkey, which 
is a well-known alternative measure of globalization (Guillén 2001). These organizations can be classified as nongovernmental organizations, intergovernmental organizations, and international nongovernmental organizations. All these organizational actors play their role in global politics and are considered as an important indicator of globalization. The increase in the number of international organizations constitutes an institution-building process, reflecting the relative power of international and global political actors (Chase-Dunn 1999). Hence, the number of international organizations in a country is an indicator of this country's degree of integration into the global world. We collected these data from the online database of The Yearbook of International Organizations, which is published by the Union of International Associations. ${ }^{12}$ The correlations between this alternative globalization measure, on the one hand, and the overall KOF globalization index and its subdimensions (economic, political, and social), on the other hand, are very high: $.98, .96, .94$, and .91 , respectively.

As a second robustness check, we compare Turkish economic growth (in GDP per capita) with globalization (through the KOF index and its three dimensions) over time. Recall that figure 1 reveals a strong increase in all KOF globalization indices until 1994, after which growth seem to taper off. Figure 4 provides Turkish GDP per capita, indicating a different pattern: GDP per capita is increasing for the whole observation period and even accelerates after 2000. This suggests that economic growth follows the globalization trend and that economic development and globalization (as measured by the KOF index) are different measures.

We employ variables at the local level in order to analyze the characteristics that moderate the impact of globalization. To explore hypothesis 2, we include the interaction of the KOF globalization index and the percentage of votes that the most religious parties received at the district level in parliamentary elections (variable label traditional Islamic votes), with which we capture ideological movements that oppose globalization. ${ }^{13}$ The political parties are classified on a secular/religious scale, ranging from 1 (the most secular) to 10 (the most religious). This scaling was done by the first author (of Turkish nationality) and was cross-checked by Turkish political scientists (table A1 in the appendix lists all parties that ever participated in elections during our study period and the secular/religious score attached to each party). ${ }^{14}$

\footnotetext{
${ }^{12}$ Note that this variable does not cover as much information as the KOF globalization index.

${ }^{13}$ The election outcomes at time $t$ were used to fill in the subsequent years without parliamentary elections. Our measure was updated each time an election occurred. The same procedure was used for the ideological polarization variable described below.

${ }^{14}$ The most religious parties are the ones that score 10 on the secular/religious scale.
} 


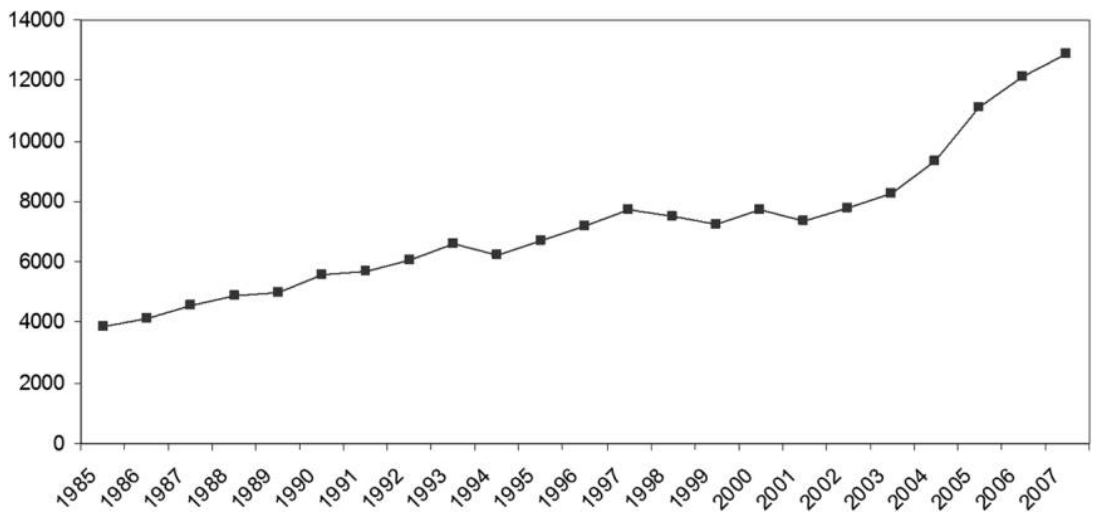

FIG. 4.-GDP per capita in Turkey (in U.S. dollars), 1985-2007

To test hypothesis 3, we include the interaction terms of the density of Imam Hatip and Anatolian high schools with the globalization index, as Imam Hatip and Anatolian high schools are the parent forms of the hybrid Anatolian Imam Hatip high schools. That is, as both parent forms are combined in the hybrid high school form, we add a three-way interaction of both parent form densities with the globalization index (next to all two-way product terms).

The independent variable key to hypothesis 4 is the interaction of the KOF globalization index and the growth of the number of employers at the district level, which is our proxy for the proglobalization economic incentives associated with a district's entrepreneurial community. We include the growth of the number of employers at the district level as our measure of local economic incentives. This variable is obtained from the National Education Statistics, as published annually by the Prime Ministry State Institute of Statistics.

Regarding hypothesis 5, we add the interaction of the KOF globalization index and a polarization measure. We use the polarization index proposed by Esteban and Ray (1994) in order to measure the secular-religious polarization of local communities at the district level (variable label ideological polarization). This polarization index is based on the Gini coefficient that takes into account both the size of the subgroups and the distance between the polarized groups: ${ }^{15}$

15 The measurement of the distance between groups depends on the context. In our case, the distance between the polarized groups refers to the distance in terms of secularreligious orientation of the community at the district level. 
American Journal of Sociology

$$
P=k \sum_{i=1}^{N} \sum_{j=1}^{N} \pi_{i}^{1+\alpha} \pi_{j}\left|y_{i}-y_{j}\right|,
$$

in which $k$ is the scaling factor, $\pi$ denotes the size of the groups, $\left|y_{i}-y_{j}\right|$ gives the distance between groups $i$ and $j$, and $\alpha$ parameterizes the degree of polarization sensitivity that takes a value between zero and 1.6 (Esteban and Ray 1994). This measure captures the intuition that polarization is high when there is a large distance between a small number of groups of significant size. We measure the size of the groups by using the proportional number of votes that political parties received in parliamentary elections at the district level. The distance between the polarized groups is measured by means of the classification of political parties ranging from 1 (most secular) to 10 (most religious), mentioned above. We set $k=1$ and $\alpha=0.8 \cdot{ }^{16}$ Hence, we follow most researchers by giving a balanced weight to the size of and the distance between the subgroups. We ran robustness analyses with $\alpha=0.4$ and $\alpha=1.2$, which produced a pattern of findings similar to what we report below (available on request).

\section{Control Variables}

We control for carrying capacity by including the percentage of government expenditures devoted to education at the country level, as well as national GDP growth and the logarithm of the population size at the district level. ${ }^{17}$ We added a dummy variable to control for the years following a territorial change of a few districts (one for the years after the change and zero otherwise). For the different official regions in Turkey (i.e., the Aegean, Black Sea, Central Anatolian, Eastern Anatolian, Marmara, Mediterranean, and Southeastern Anatolian regions), we introduce dummies that take a value of one if the district is in that region and zero otherwise. At the district level, we control for the density of previously founded hybrid high schools and the densities of the parent high schools forms (Anatolian and Imam Hatip high schools). Finally, regular high school density is added to control for the general expansion of the high school system in Turkey. We take the one-year lagged values of all variables (except for the dummy variables and the two variables based on election outcomes, i.e., traditional Islamic votes and ideological polarization, as the latter two are constant between election periods

\footnotetext{
${ }^{16}$ Since $k$ is a multiplicative constant, it does not have any qualitative effect on the results (Esteban and Ray 1994).

${ }^{17}$ In further robustness analyses, to be discussed below, we added real GDP per capita as a control variable (available on request).
} 
so that an additional one-year lag is not informative) in order to avoid simultaneity.

\section{Model Specification}

The dependent variable is a count of the yearly number of newly established hybrid schools in the district. The distribution of count variables is typically highly skewed to the right with many observations that are zero or close to zero, all values being nonnegative. As it is preferable to use methods that are consistent with the underlying process that generates the founding events observed as nonnegative aggregate counts, it is recommended in the literature to use Poisson regression to analyze founding rates (Hannan and Freeman 1987, 1989; Barron and Hannan 1991; Carroll and Hannan 2000). However, in the case of overdispersion (i.e., the variance of the count is larger than the expected mean), Poisson regression underestimates the coefficients' standard errors, leading to inflation of significance levels (McCullagh and Nelder 1989; Wezel 2005). Then, negative binominal regression should be applied, which adds a stochastic error component, following a gamma distribution, to the model (Barron and Hannan 1991; Cattani, Pennings, and Wezel 2003). This method has become the standard in organizational sociology to analyze aggregate founding data of the kind we collected in our project (see Carroll and Hannan 2000).

Following Baron, Hannan, and Burton (2001), we use Liang and Zeger's (1986) method of generalized estimating equations (GEE), which generalizes quasi likelihood estimation to the panel data context. GEE is a very flexible approach that allows one to control for many different forms of correlated error terms, including serial autocorrelation, by using an empirical variance estimator (Barron and Hannan 1991; Baron et al. 2001; Ballinger 2004). As recommended by Barron and Hannan (1991) in the context of the analysis of longitudinal founding rates, we assume a first-order autocorrelation structure to control for (potentially remaining) serial autocorrelation among error terms. GEE also allows us to account for the likelihood of nonconstant variance for different values of the dependent variable due to clustering of observations within the district by using the Huber-White Sandwich estimator to estimate the standard errors (i.e., robust standard errors for clustering of observations in the district). All models are estimated using the XTGEE routine of version 10.0 of Stata.

A few other estimation-related issues are worth mentioning. First, we checked for nonstationarity of our dependent variable, as this might lead to spurious relationships. Figure 5 plots the number of foundings of hybrid high schools over time. Visual inspection suggests that this time series is not trended and, thus, stationary. Given that there are no exit events in 


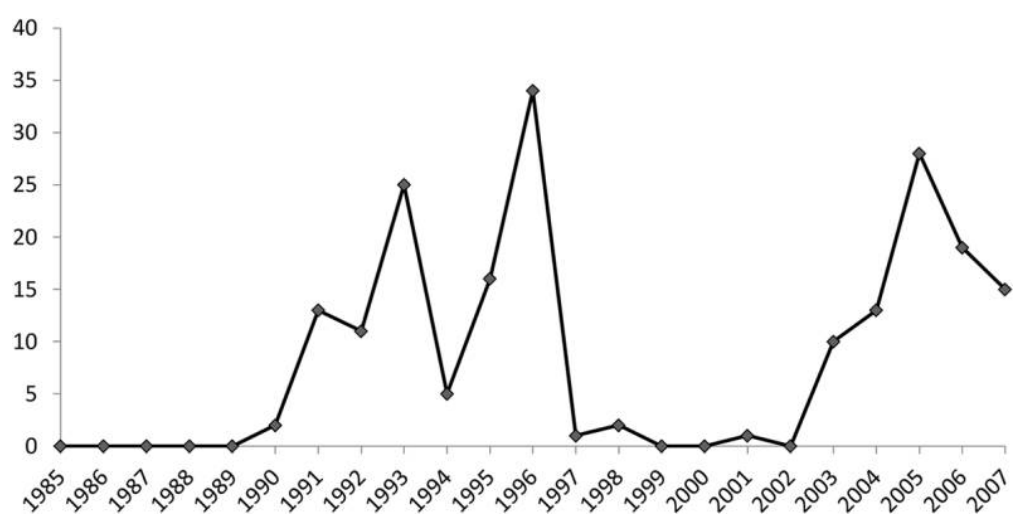

FIG. 5.-Foundings of hybrid schools at the level of Turkey, 1985-2007

the period under study, the founding count is, in fact, a first-difference variable of hybrid school density at time $t$ minus $t-1$. It is well established that even nonstationary series generally become stationary after taking the first difference. A Fisher type unit root test for unbalanced panel data formally reveals that we can reject the null hypothesis that all district-level time series are nonstationary against the alternative hypothesis that at least one series in our panel is stationary. ${ }^{18}$ We continued with Dickey-Fuller unit root tests for each district separately. Our results indicate that the series of almost all districts (except for two) are stationary as the null hypothesis of a unit root has to be rejected. ${ }^{19}$ Taking all this together, we conclude that nonstationarity of our major dependent variable does not represent a serious threat to the statistical inferences made in the article.

Second, we ran conditional fixed-effects negative binomial regressions (available on request). Of course, by doing so, we filter out the between-district variation that is essential from the perspective of our theoretical logic, which stresses the importance of geographical heterogeneity in explaining whether and how local communities adjust to globalization. An additional drawback of fixed effects in this setting is that we lose the observations of the few districts that never experienced a founding event (i.e., 58 district-year observations). However, notwithstanding this removal of theoretically relevant cross-district heterogeneity, which comes with drops in significance levels,

\footnotetext{
${ }^{18}$ Note that we have 81 panels (districts). For 67 panels, we have data points for the whole period under study ( 23 observations); for the remaining 14 districts, we have between nine and 19 observations because these 14 districts were established only after 1985 (i.e., in the 1980s, 1990s, and 2000s). So our panel is unbalanced.

${ }^{19}$ Note that most of the standard unit root tests (such as Dickey-Fuller) have low power. So in small samples per district, one may easily end up with type II errors of accepting the null hypothesis of a unit root while it is actually false (see Hamilton 1994).
} 
the estimates are highly sign consistent, which offers further support for the robustness of our findings.

\section{FINDINGS}

Descriptive statistics and bivariate correlations are reported in table 1. Table 2 provides our GEE negative binomial regression estimates of the founding rate of hybrid high schools at the district level.

We first focus on the effects of globalization and the control variables. Model 1 reveals that the main effect of globalization is significantly positive $(B=.10 ; P<.001)$, providing support for hypothesis 1 predicting that globalization spurs the founding rate of hybrid high schools. In addition, national GDP growth and percentage of educational expenditures have a positive impact on hybrid high school founding. Moreover, Marmara being the omitted region, we observe that the hybrid high school founding rate is lower in eastern, southeastern, and central Anatolian regions. At the district level, district population and the most religious votes have a positive effect, whereas secular-religious polarization has a negative impact on the emergence of hybrid high schools. ${ }^{20}$ Density of regular high schools does not have any significant effect. The model 1 estimates further suggest that the densities of Imam Hatip and Anatolian high schools both have a positive influence on the emergence of hybrid high schools $(B=.14$ and $B=.06$, respectively; for both estimates, $P<.001$ ), suggesting positive spillover effects of the parent templates.

A perhaps counterintuitive finding is the significantly negative sign of lagged hybrid school density. After all, the increase in the number of hybrid high schools in a district could have a legitimation effect, predicting a positive sign. What may explain our negative coefficient is a carrying capacity effect. That is, in a district with a certain population size, there is a natural limit to the demand for a certain high school type, which puts an upper boundary to the number of high schools of that type that can be viably established in a district. To check for this interpretation, we ran the models without the densities of other high school types: the results reported in the article do not change (including the sign of the lagged density of hybrid high schools; the results are available on request). In addition, we ran the same models by

${ }^{20}$ The finding that the traditional Islamic votes and ideological polarization have a positive and negative main effect, respectively, on the founding rate of hybrid schools might seem surprising at first glance. However, note that in subsequent models we show that these variables significantly interact with globalization, making the interpretation of main effects not very meaningful. On a more substantive level, the overall pattern of findings reported below suggests that the impact of globalization on hybrid school foundings is very strong even in communities that might resist and that the local context mainly attenuates the overwhelming force of globalization. 


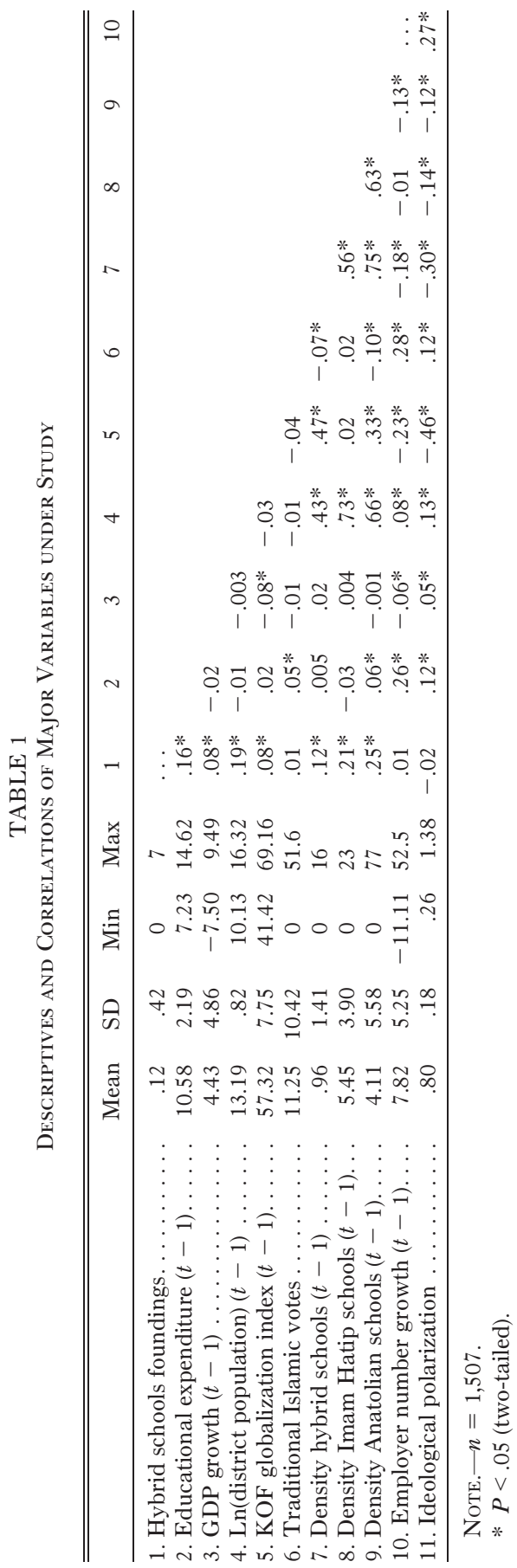

This content downloaded from 146.175.120.121 on June 15, 2017 07:55:23 AM 
replacing the dependent variable (founding rate of hybrid high schools) with the founding rate of Imam Hatip high schools and Anatolian high schools, one by one, with and without the density of the other high school types (available on request). We found negative (and significant) coefficients for the lagged densities of Imam Hatip and Anatolian high schools, respectively, in all these supplementary analyses. These findings offer further support for our carrying capacity explanation of the negative sign of the coefficient of the lagged density of hybrid high schools.

In model 2, we see that the proportion of the most religious votes (traditional Islamic votes) attenuates the impact of globalization on the hybrid high school founding rate $(B=-.002 ; P<.05) .{ }^{21}$ Strong support for a traditional interpretation of Islam apparently hampers the local community from adapting to global norms because of a lack of resonance between the global and the local, a finding that is in line with hypothesis 2 .

In model 3, we report the three-way interaction of the KOF globalization index and the densities of Imam Hatip and Anatolian high schools to test for hypothesis 3's prediction that the joint presence of both parent forms moderates the impact of globalization by providing the institutional repertoire for hybrid high school formation. The two-way interactions of both densities with globalization separately are negative, but the three-way interaction is significantly positive as expected $(B=.003 ; P<.01)$. This pattern of findings underscores that the positive impact of globalization on hybrid high school foundings increases when both types of parent high schools are prevalent in the district.

In model 4, we find support for hypothesis 4 . The effect of globalization on hybrid high school formation increases with the growth in the number of employers in a local district $(B=.01 ; P<.05)$. This finding suggests that a strong entrepreneurial climate in a district provides the economic incentives to adapt to global norms, values, and practices by blending the local with the global. Finally, the estimates of model 5 offer evidence for hypothesis 5, showing a significantly positive interaction coefficient between the $\mathrm{KOF}$ globalization index and ideological polarization $(B=.21 ; P<.001)$. Secular-religious polarization acts as a mobilizing force for rival ideologies, triggering the ideological incentives for local adaptation when globalization increases.

To further explore our argument, we performed a post hoc analysis by estimating model 6, which includes the interaction between religious votes (hypothesis 2), on the one hand, and the growth of the number of employers

\footnotetext{
${ }^{21}$ Note that, for the traditional Islamic votes variable, we included only the political parties that receive a score of 10 on the religiosity scale. As a robustness check, we also added the political parties that score 8 and 9 on this scale. The results remain the same (available on request).
} 


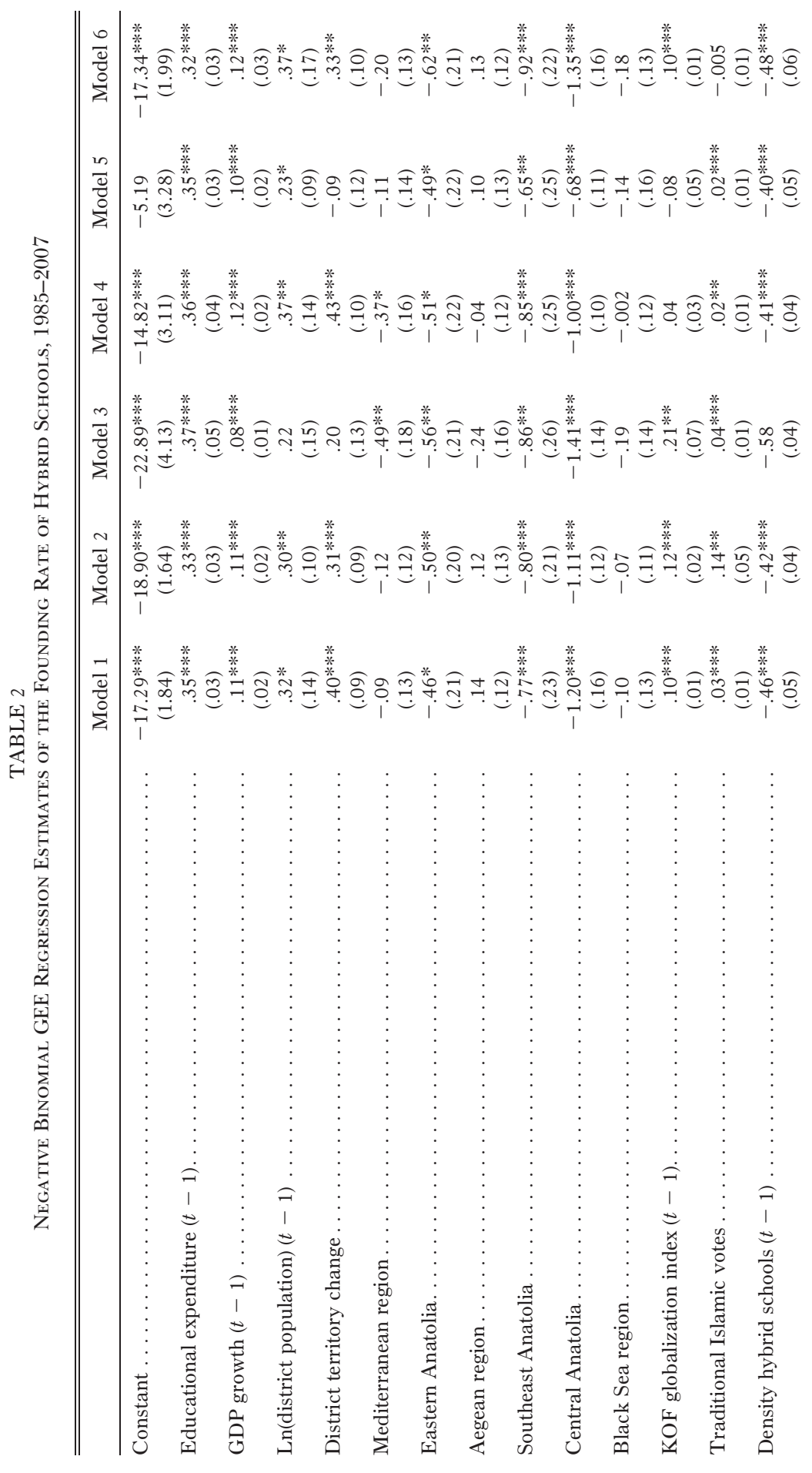

1852

This content downloaded from 146.175.120.121 on June 15, 2017 07:55:23 AM 


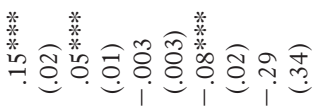

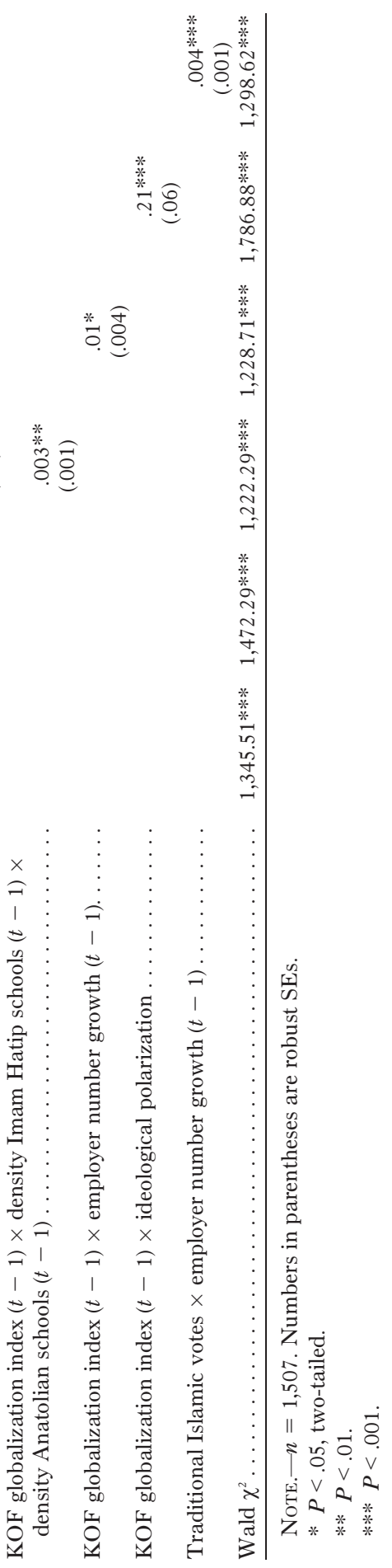

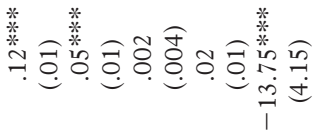

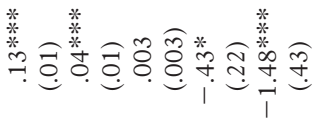

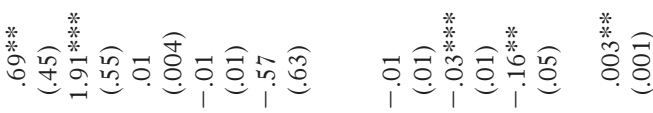

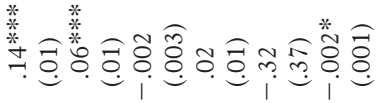

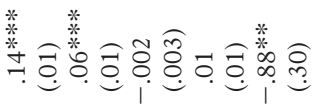

1853 
(hypothesis 4), on the other. The significantly positive estimate supports the underlying argument that a larger Islamic faction promotes alternative modernities (Robertson and Khonder 1998), particularly in a community that features a strong local entrepreneurial culture $(B=.004 ; P<.001)$.

\section{Robustness Analyses}

In our main analyses reported in this article, we decided against including (lagged) GDP per capita because of the high correlation of this control variable with our (lagged) KOF globalization index (.87), which causes potential problems due to multicollinearity. It is well known that this inflates standard errors of estimates, reducing $t$-statistics and significance levels. However, to disentangle the effect of these variables, we compared models with both variables entered separately and simultaneously (results are available on request). Both GDP per capita and the KOF globalization index are significantly positively related to the founding rate of hybrid high schools when entered separately in the regression equation. However, when entered simultaneously, the estimate of GDP per capita becomes insignificant, even with a negative sign, whereas the effect of the KOF index is not affected compared to the estimate reported in model 1 of table 2 (i.e., $B=.11 ; P<.001$ ). This comparative analysis suggests that the emergence of hybrid high schools is indeed driven by globalization, and not by the steady growth of GDP per capita during our observation window, notwithstanding the fact that both are strongly related because globalization has had a huge impact on subsequent economic growth in Turkey (see also the comparison between both time series in figs. 1 and 4 discussed above). ${ }^{22}$

Second, we ran an analysis with the number of nonprofit international organizations (IOs) that have headquarters in Turkey as an alternative measure of globalization, replacing the (lagged) KOF globalization index with the (lagged) number of IOs headquartered in Turkey (results are available on request). All findings turn out to be very robust, which is hardly surprising given the high correlation between the alternative IO measure and the KOF globalization index (see above). This additional analysis provides further support for both the validity of the KOF globalization index and the robustness of our results.

Third and finally, we ran separate analyses for the economic, political, and social dimensions of the KOF globalization index. The results are sum-

\footnotetext{
${ }^{22}$ To be on the safe side, we also reestimated all interaction effects with the KOF globalization index now including GDP per capita as a control variable. This does not qualitatively change the findings reported in table 2. Only the significance level of the interaction effect of KOF globalization index $\times$ employer number growth slightly drops to the $10 \%$ level (results available on request).
} 
marized in table 3 (full results are available on request), reporting only the relevant estimates regarding KOF's three dimensions.

For the economic globalization index, we find support for all hypotheses except hypothesis 4; for the political globalization index, we observe only evidence in favor of hypotheses 1 and 3; and for the social globalization index, all hypotheses are supported. Note, however, that the signs of all interaction estimates are the same. We further discuss this set of additional findings in the concluding section.

\section{DISCUSSION}

In this article, we analyze the impact of globalization on the emergence of hybrid organizational forms, finding support for a positive main effect. We propose that the impact of globalization depends on three local characteristics: the potential misfit between global and local ideas, values, and practices (local resistance); the presence of institutional repertoire to blend into hybrid organizational forms (local templates); and the motivation of the local community to adapt to global ideas, values, and practices (local incentives). We test our hypotheses in the setting of Islamic education in Turkey between 1985 and 2007. In this period, Turkey experienced a growing impact of globalization in combination with the rise of an Islamic movement, with large variation across the country. This setting is highly appropriate for our purposes, with clear forces of globalization and localization operating next to one another.

Regarding the effect of local resistance, our evidence suggests that in the most religious, traditional local communities, the impact of globalization on hybrid high school formation is attenuated. The more local people vote on the most religious parties, the less likely local high schools are established that blend cosmopolitan and religious norms, values, and practices into a hybrid form in response to increasing globalization. Then globalization presents a threat to local traditions, as westernization clashes with the local, which triggers strong resistance among the large traditionalist fraction of the community against the global model of education. This in turn hampers the willingness of the local community to recombine global and traditional educational templates into a hybrid school form. Such communities are less susceptible to adapting to global boundary-blurring forces, which often demarcates traditional boundaries between the global and the local more sharply (Marquis and Batillana 2009).

As far as the role of local templates is concerned, we find that the founding rate of the hybrid high school form increases with the number of parent high school forms, namely, Anatolian and Imam Hatip high schools. As a consequence of the experience of the local community with different organizational parent forms and the legitimacy that spills over from these parent 


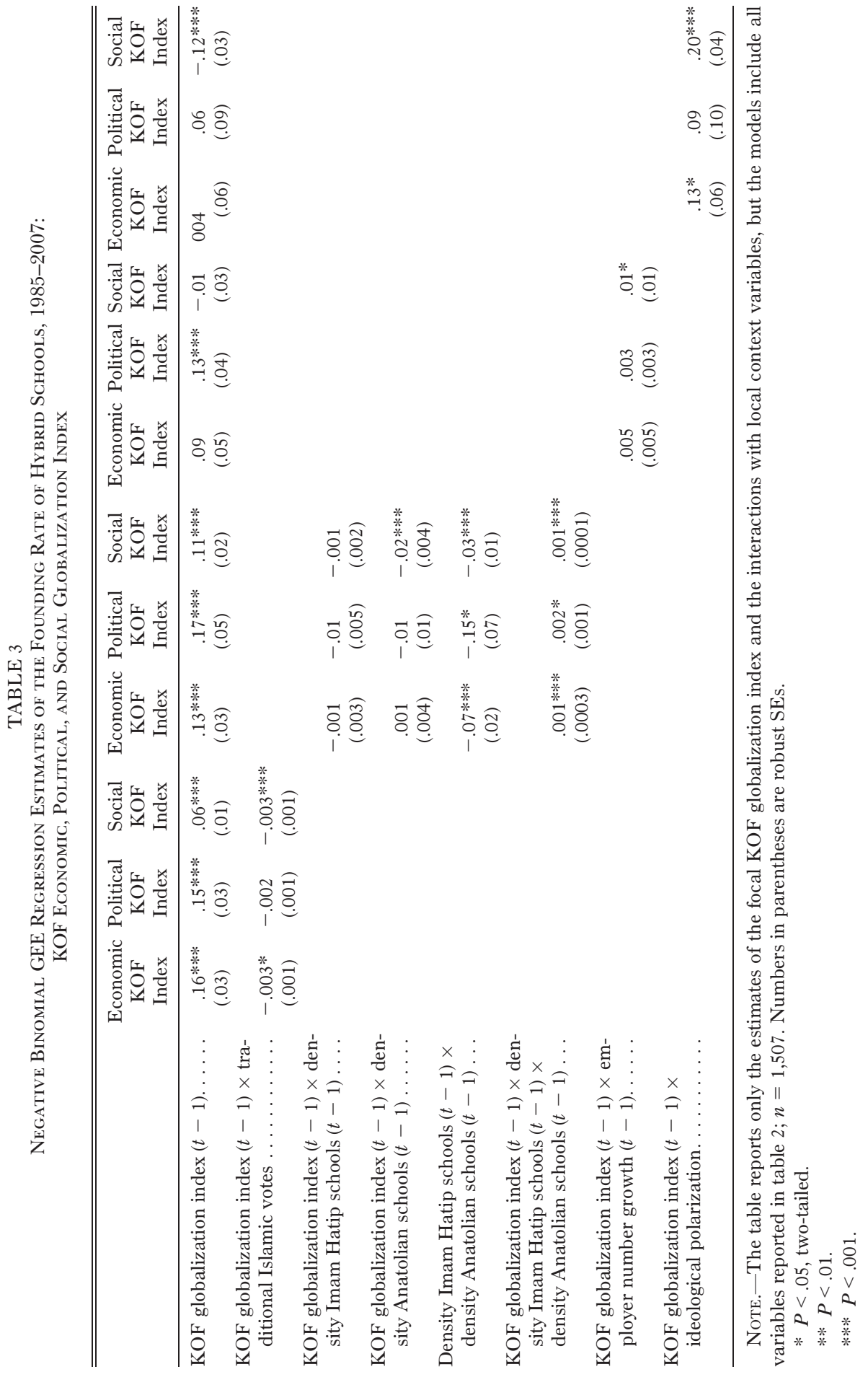

This content downloaded from 146.175.120.121 on June 15, 2017 07:55:23 AM 
templates to their combination in hybrid forms, the establishment of Anatolian Imam Hatip high schools is facilitated. The presence of parent forms in a local community together with increases in globalization, therefore, spur hybrid high school founding. This underscores the observation that "thinkable" alternative templates that emerge in response to societal change are often building on existing institutions (Haveman and Rao 2006; Schneiberg and Clemens 2006).

Relating to local incentives, we find that the impact of globalization on the founding rate of hybrid high schools increases with the growth in the number of employers in a local district, as well as with secular-religious polarization. This provides evidence for our claim that both economic and ideological incentives trigger local communities to respond to forces of globalization by establishing hybrid organizational forms that blend the global with the local. That is, a strong local entrepreneurial culture that resonates with economic globalization stimulates adaptation to benefit economically from globalization. Local ideological polarization is another mobilizing force as this intensifies direct ideological competition among different community fractions. Because of globalization, cosmopolitan education based on scientific, rational principles gained importance all over the world. ${ }^{23}$ In such circumstances, more traditional members of a community are incentivized to adjust to the Western model of education to keep up with the secular fraction in a globalizing world. One way is to insert key elements of the cosmopolitan template of education in Islamic education without sacrificing one's religious identity.

In post hoc analyses, we further explored the underlying mechanism by estimating the interaction between the most religious votes and growth in the number of employers. Although the proportion of the most religious votes has a negative moderating effect on the hybrid high school founding rate, we find that such local communities do adapt to the global world when the community has a strong local entrepreneurship culture. One interpretation is that adaptation is then instrumental for the traditional religious community in the sense that the local religious population is motivated to blend the global with the local in order to gain from this economically without sacrificing too much their local identity. A hybrid organizational form such as the Anatolian Imam Hatip high school serves this purpose by merging key elements of cosmopolitan education into an otherwise Islamic teaching tradition.

We ran a series of additional analyses to explore the robustness of our findings. Indeed, our results survive changes in the estimation method, the

${ }^{23}$ Following Meyer (2000), we use "rationalism" to refer to the convergence of educational templates based on science. According to Meyer and his colleagues, both organizations and actors are subject to standardizing rationalization because of globalization that arises from a scientific analysis of nature as universal and lawful. 
set of control variables, or the measure of globalization. Substantively, the robustness analyses regarding the different dimensions of globalizationeconomic, political, and social — are particularly interesting. These analyses reveal that economic and, particularly, social globalization is important to explain the emergence of hybrid high school forms, whereas political globalization is not. Indeed, this finding is in line with our result that economic and ideological incentives provide the motivation to adapt to the global while preserving the local. Apparently, political globalization per se does not suffice to affect people's motivation, perhaps because such globalization does not seriously affect the local communities' norms and values. This underscores that globalization is also an ideology (Guillén 2001), which takes time to become part of the cultural mind-set of local communities. As a result, it is unsurprising that the social dimension of globalization reveals the largest effects on the emergence of hybrid high schools in Turkey.

Post hoc, we also estimated models to further explore the effect of our main variables on the founding rate of Anatolian and Imam Hatip high schools (results are available on request). These analyses reveal that globalization has a significantly positive impact on the founding of Anatolian high schools, as these schools are the carriers of cosmopolitan values and norms ever since their foundation. However, globalization has a significantly negative effect on the founding of Imam Hatip high schools, as they are out of tune with the increasing influence of globalization. Conversely, a larger share of the most religious votes has a negative main impact on the founding rate of Anatolian high schools but stimulates the founding rate of Imam Hatip high schools. Interestingly, polarization reduces the founding rate of Imam Hatip high schools (but not that of the Anatolian schools). Overall, the results from these supplementary analyses reflect our main findings regarding Anatolian Imam Hatip high schools. The pattern of findings suggests that two trends dominate in Turkey. On the one hand, a globalization trend spurs cosmopolitan education, boosting Anatolian high school founding; on the other hand, local religious traditions oppose this trend, favoring Imam Hatip high school founding (and more so when globalization pressures increase). Only when local polarization is high do local communities (with the most religious voters) "adjust" to increasing globalization by the establishment of hybrid Anatolian Imam Hatip high schools.

In this study, we built on institutional and glocalization theories and combined those with insights from organizational ecology in order to understand the impact of globalization on the emergence and expansion of hybrid organizational forms. Hence, our article contributes to the literature in several ways. First, until recently, most institutional theory has mainly focused on how higher-order institutional pressures affect lower-level mimetic behavior leading to field-level convergence (Schneiberg and Clemens 2006). Communities and organizations are regarded as relatively passive recipients 
of top-down institutional pressures (DiMaggio and Powell 1983), giving a somewhat "deterministic" flavor to institutional theory (Marquis and Batillana 2009). Our approach underscores the important role of agency and contestation in whether and how actors are willing to adjust to these pressures. How institutional pressures, such as globalization processes, unfold depends on place-bound features and therefore requires a systematic study of the heterogeneity among communities and their organizations. The bottom line is that actors have a range of responses available when facing institutional pressure (see also Oliver 1991). Building on glocalization theory, we show that local cultures may critically adapt or resist global phenomena and that the creation of localities is a standard component of globalization (Robertson and Khonder 1998). In order to understand when, where, and why hybrid organizational forms emerge as a reaction to globalization, it is important to analyze the local characteristics that moderate the impact of globalization. Our study is one of the first systematic, comparative empirical studies analyzing the impact of this interplay on the emergence of hybrid organizational forms, focusing on the role of local resistance, local templates, and local incentives.

The usefulness of this comparative institutional approach is witnessed by the fact that it allows us to reconcile the many conflicting outcomes of globalization that have been discussed in the literature, ranging from convergence via hybridization to divergence. Indeed, our findings suggest that the specific outcome of globalization depends on local conditions in a predictable way. We also show that different versions of modernity might emerge depending on the specific interplay between the global and the local. Modernity is therefore not inherently globalizing, as Giddens (1990) argued. Globalization is an ideology subject to contestation (Guillén 2001). What Western people define as modernity is not what other movements such as Islam and Marxism claim (Robertson 1992; Guillén 2001). Out of contestation, alternative models emerge, fueling pluralistic identities that compete for dominance. As Geertz (1998, p. 107; cited by Guillén 2001) observes, the world "is growing both more global and more divided, more thoroughly interconnected and intricately partitioned at the same time."

In the context of our study, the diffusion of the hybrid high school form that educates young people to become world citizens who compete for elite functions illustrates that Islam is becoming a global force itself, defining a competing logic in parallel with Western modernity. This is also demonstrated by the steady growth of the Gülen movement, a transnational religious and social force that has been described as the world's most global movement (Göle 2000; Kuru 2003). This movement, led by the Turkish Muslim thinker Fethullah Gülen, is active in education with schools in more than 140 countries and also invests in media, finance, and for-profit health clinics. The education offered by the Gülen movement is similar to that of 
the Turkish hybrid high schools, blending global rationalized principles of education with Islam. The purpose is to form a new synthesis between science and religion, reason and revelation, and progress and conservatism inspired by Islam (Kuru 2003) and to encourage practicing Muslims to be active participants in a globalizing world. Unsurprisingly, this movement, in turn, is contested in Western nation-states, such as in the United States and the Netherlands, questioning the good intentions of the movement.

Our study also contributes to organizational ecology, which has a particular interest in explaining where and why new organizational forms emerge to understand the dynamics of organizational diversity (McKendrick et al. 2003; Boone and Özcan 2014; Bogaert et al. 2016). This literature further recognizes that organizations are important carriers of ideology that fuel contestation, social change, and adaptation (Barnett and Woywode 2004; Simons and Ingram 2004; Sine and Lee 2009). For instance, cooperative organizations often emerge in response to corporations out of anticorporate sentiments in order to defend the "commonwealth" logic against the dominant "mass market" logic (Schneiberg et al. 2008; Boone and Özcan 2014). In a similar vein, the educational system responds to globalization by building hybrid schools that serve the purpose of defining and diffusing an alternative form of Islamic modernism. Clearly, organizations are important vehicles of institutional change. Therefore, the study of how organizational dynamics coevolve with institutions is of great importance, although this issue received insufficient attention in prior work (Haveman and Rao 2006).

Our particular focus on explaining the emergence of hybrid organizational forms implies an additional contribution. Because hybrid organizational forms build on existing institutional templates, they represent institutional carriers that allow for incremental institutional change, as opposed to discontinuous change, where one logic is discarded and replaced (Haveman and Rao 2006). Despite their importance, little attention has been paid to the processes that lead to the emergence of hybrid forms and under which conditions boundaries dissolve to produce hybridity (Lamont and Molnar 2002). In this article, we analyze the role of globalization on institutional change that leads to the mixing of blueprints belonging to opposing categories, which is a widely neglected topic in the literature (Rao et al. 2005). This is an important omission, as literature shows that hybrid forms meet sharp punishment, particularly if the category codes are oppositional or involve moral imperatives (Kovács and Hannan 2010). Our study suggests, however, that if the community has a lot at stake and therefore has a strong motivation for blending oppositional categories, then hybrid forms might emerge without getting penalized. Thus, to understand the emergence of hybrids, it is essential to take into account the underlying dynamics that trigger the adaptation process, such as the strong ideological polarization in Turkey. 
Finally, our study contributes to the extensive research program on the worldwide diffusion of education systems by Meyer et al. (1997, 2010). These scholars argue and report empirical evidence that the expansion of rationalized modernity leads to enormous convergence in educational systems all over the world. Although the convergence process is well reflected in the literature (Anderson-Levitt 2003), research has paid less attention to the variation across different societies and the reasons behind this variation. In our study, we focused on a more fine-grained community-level analysis, showing that variation indeed matters. Although this seems to undermine the education-system convergence thesis, it is important to stress that Meyer and Hannan (1979) claimed that isomorphism relates to structural similarity (socalled similarities of form), however decoupled from purpose and intentions (see also Guillén 2001). Interestingly, this seems to fit with the Anatolian Imam Hatip high schools we studied: the scientific/rational template is copied while the local religious-inspired values defining purpose and intentions are retained.

Our study is not without limitations, which provide opportunities for further research. Here, we would like to mention three such opportunities. First, our data offer the opportunity for more detailed studies of the underlying dynamics of district-level movements and countermovements in interaction with country-level globalization. For instance, we may examine the differences in the speed of adjustment (or the strength of resistance) across different Turkish districts in response to forces of globalization. Another example is a study of reversed causalities. In our specification, we took care of this by lagging our key independent variables, but this does not exclude an impact of district-level dynamics on globalization: the founding of cosmopolitan or hybrid high schools may foster forces that may contribute to globalization.

Second, there is the question as to the extent to which our results are generalizable to other settings. Given that globalization is a very broad topic and that there are many different studies in different fields, this question is difficult to answer. However, we see that similar hybrid organizational forms emerge as a consequence of globalization in other domains of society, an example being Islamic banks (Segrado 2005). Islamic banks operate according to the principles of Islamic law. Yet, at the same time, the products and services provided by Islamic banks are similar to the ones offered by conventional banks. Islamic banks are hybrids in the sense of combining modern methods of business and finance with Islamic laws concerning economics. Another example is the emergence of the integrated Islamic high schools in Indonesia, also in the 1980s (Hasan 2009). These schools combine Islamic education with a modern curriculum, too, and are preferred by the elite class. The reasons behind the emergence of these hybrid school forms can probably be explained by local characteristics similar to the ones in Turkey, such as the growing entrepreneurial class in Indonesia. And another driver 


\section{American Journal of Sociology}

may well be the ideological polarization within the different sects of the Muslim population and between different religions (Hasan 2009).

Third, of similar interest would be to study contexts in which hybrid organizational forms fail to emerge. Only then can we really understand the boundary conditions of our theory. The examples above suggest that the emergence of hybrid organizational forms follows from the presence of both segregating and blending forces, particularly for the emergence of hybrid forms that carry rival ideologies. In the Muslim world, Turkey might be a special case because of the powerful secular movement, as initiated by Ataturk in the early 20th century. Perhaps such a national secular policy is a precondition for embracing cosmopolitan and globalized patterns. For that reason, the emergence of hybrid schools in a country like Iran is not very likely because of the absence of strong blending forces. In future work, we hope to further develop the comparative perspective implied by the theory proposed in the current study.

\section{APPENDIX}

TABLE A1

Political Parties and Score on the Secular-Religious Scale (1 to 10 )

\begin{tabular}{|c|c|}
\hline Political Parties & $\begin{array}{c}\text { Secular/ } \\
\text { Religious } \\
\text { Scale }\end{array}$ \\
\hline Changing Turkey Party (Degisen Turkiye Partisi): 1998-2002 & 2 \\
\hline Communist Party of Turkey (Turkiye Komunist Partisi): 2001- & 1 \\
\hline Democratic Left Party (Demokratik Sol Parti): $1985-\ldots \ldots \ldots \ldots \ldots \ldots$ & 2 \\
\hline Democratic Party (Demokratik Parti): $1970-80 \ldots \ldots \ldots \ldots \ldots$ & 8 \\
\hline Democratic Turkey Party (Demokrat Turkiye Partisi): 1997-2005 & 7 \\
\hline Democracy and Peace Party (Demokrasi ve Baris Partisi): 1996-2002 . & 1 \\
\hline 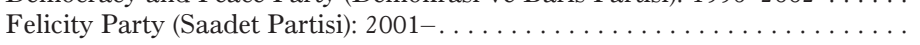 & 10 \\
\hline Great Union Party (Buyuk Birlik Partisi): $1993-\ldots \ldots \ldots \ldots \ldots \ldots \ldots \ldots$ & 8 \\
\hline Homeland Party (Yurt Partisi): 2002-. & 7 \\
\hline Independent Turkey Party (Bagimsiz Turkiye Partisi): 2001- . . . . . & 10 \\
\hline Justice and Development Party (Adalet ve Kalkinma Partisi): $2001-$. & 8 \\
\hline 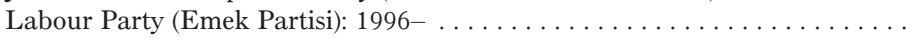 & 1 \\
\hline Liberal Democratic Party (Liberal Demokrat Parti): $1995-\ldots \ldots \ldots \ldots \ldots \ldots$. . . & 5 \\
\hline Motherland Party (Anavatan Partisi): $1983-\ldots \ldots \ldots \ldots \ldots \ldots \ldots \ldots$ & 7 \\
\hline Nation Party (Millet Partisi): $1992-\ldots \ldots \ldots \ldots \ldots \ldots \ldots \ldots \ldots \ldots$ & 8 \\
\hline Nationalist Democracy Party (Milliyetci Demokrasi Partisi): 1983-86. . . . . . & 5 \\
\hline Nationalist Movement Party (Milliyetci Hareket Partisi): $1969-\ldots . . . \ldots \ldots$. & 8 \\
\hline Nationalist Working Party (Milliyetci Calisma Partisi): 1983-93 . . . & 9 \\
\hline New Democracy Movement (Yeni Demokrasi Hareketi): 1994-97 . . & 5 \\
\hline 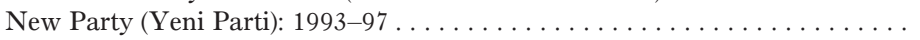 & 7 \\
\hline Freedom and Solidarity Party (Ozgurluk ve Dayanisma Partisi): 1996- . . . . & 1 \\
\hline 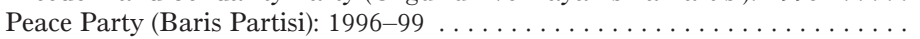 & 1 \\
\hline People's Ascent Party (Halkin Yukselisi Partisi): $2005-\ldots \ldots \ldots \ldots$ & 8 \\
\hline People's Democracy Party (Halkin Demokrasi Partisi): 1994-2003 . . & 1 \\
\hline People's Party $($ Halkci Parti): $1983-85 \ldots \ldots \ldots \ldots \ldots \ldots \ldots \ldots \ldots$ & 2 \\
\hline
\end{tabular}




\begin{tabular}{|c|c|}
\hline Political Parties & $\begin{array}{c}\text { Secular/ } \\
\text { Religious } \\
\text { Scale }\end{array}$ \\
\hline Rebirth Party (Yeniden Dogus Partisi): 1992-2002. & 5 \\
\hline Reformist Democracy Party (Islahatci Demokrasi Partisi): 1984-92 & 8 \\
\hline Republican People's Party (Cumhuriyet Halk Partisi): $1923-\ldots \ldots \ldots \ldots \ldots$. . . . & 2 \\
\hline Social Democratic Populist Party (Sosyaldemokrat Halkci Parti): 1985-95 . . . & 2 \\
\hline Socialist Government Party (Sosyalist İktidar Partisi): 1993-2001 . . . . . . . . . & 1 \\
\hline Socialist Party (Sosyalist Parti): $1988-92 \ldots \ldots \ldots \ldots \ldots \ldots \ldots$ & 1 \\
\hline True Path Party (Dogru Yol Partisi): $1983-\ldots \ldots \ldots \ldots \ldots \ldots \ldots \ldots$ & 8 \\
\hline Virtue Party (Fazilet Partisi): $1997-2001 \ldots \ldots \ldots \ldots \ldots \ldots \ldots \ldots$ & 10 \\
\hline Welfare Party (Refah Partisi): 1983-98 . . . . . . . & 10 \\
\hline Worker's Party (Isci Partisi): $1992-\ldots \ldots \ldots$. . & 1 \\
\hline Young Party (Genc Parti): 2002- . . . & 5 \\
\hline
\end{tabular}

\section{REFERENCES}

Ahmad, Feroz. 1991. "Politics and Islam in Modern Turkey." Middle Eastern Studies 27 (1): $3-21$.

Anderson-Levitt, Kathryn M. 2003. Local Meanings, Global Schooling: Anthropology and World Culture Theory. New York: Palgrave Macmillan.

Ansari, Shahzad M., Peer C. Fiss, and Edward J. Zajac. 2010. "Made to Fit: How Practices Vary as They Diffuse." Academv of Management Review 35 (1): 67-92.

Ardıç, Nurullah. 2009. "Friend or Foe? Globalization and Turkey at the Turn of the 21st Century." Journal of Economic and Social Research 11 (1): 17-42.

Aydın, Ertan, and Yılmaz Çolak. 2004. "Dilemmas of Turkish Democracy: The Encounter between Kemalist Laicism and Islamism in 1990s Turkey." Pp. 202-20 in Democracy and Religion: Free Exercise and Diverse Visions, edited by David W. Odell-Scott. Kent, Ohio: Kent State University Press.

Ballinger, Gary A. 2004. "Using Generalized Estimating Equations for Longitudinal Data Analysis." Organizational Research Methods 7 (2): 127-50.

Barnett, William P., and Michael Woywode. 2004. "From Red Vienna to the Anschluss: Ideological Competition among Viennese Newspapers during the Rise of National Socialism." American Journal of Sociology 109:1452-99.

Baron, James N., Michael T. Hannan, and M. Diane Burton. 2001. "Labor Pains: Organizational Change and Employee Turnover in Young, High-Tech Firms." American Journal of Sociology 106 (4): 960-1012.

Barron, David N., and Michael T. Hannan. 1991. "Autocorrelation and Density Dependence in Organizational Founding Rates." Sociological Methods and Research 20 (2): 218-41.

Benson, J. Kenneth. 1977. "Organizations: A Dialectical View." Administrative Science Ouarterly 22 (1): 1-21.

Bergh, Andreas, and Therese Nilsson. 2010. "Do Liberalization and Globalization Increase Income Inequality?" European Journal of Political Economv 26 (4): 488-505.

Bogaert, Sandy, Christophe Boone, Giacomo Negro, and Arjen van Witteloostuijn. 2016. "Organizational Form Emergence: A Meta-Analysis of the Ecological Theory of Legitimation." Journal of Management 42 (5): 1344-73.

Boli, John, and George M. Thomas. 1999. Constructing World Culture. Stanford, Calif.: Stanford University Press. 


\section{American Journal of Sociology}

Boone, Christophe, Anil Divarci, and Arjen van Witteloostuijn. 2011. "Ideological Polarization and Organizational Form Evolution: A Study of Islamic-Secular Rivalry and High Schools in Turkey, 1971-1998." Unpublished manuscript. University of Antwerp.

Boone, Christophe, and Serden Özcan. 2014. "Why Do Cooperatives Emerge in a World Dominated by Corporations? The Diffusion of Cooperatives in the US Bio-ethanol Industry, 1978-2013.” Academy of Management Journal 57 (4): 990-1012.

Brady, David, Jason Beckfield, and Wei Zhao. 2007. "The Consequences of Economic Globalization for Affluent Democracies.” Annual Review of Sociology 33:313-34.

Campbell, John L. 2004. Institutional Change and Globalization. Princeton, N.J.: Princeton University Press.

Çarkoğlu, Ali, and Binnaz Toprak. 2007. "Religion, Society and Politics in a Changing Turkey.” Turkish Economic and Social Studies Foundation, Istanbul.

Carroll, Glenn R., and Michael T. Hannan. 2000. The Demography of Corporations and Industries. Princeton, N.J.: Princeton University Press.

Cattani, Gino, Johannes M. Pennings, and Filippo Carlo Wezel. 2003. "Spatial and Temporal Heterogeneity in Founding Patterns.” Organization Science 14 (6): 670-85.

Chang, Chi-Hung, and Chien-Chiang Lee. 2012. "Non-linearity between Life Insurance and Economic Development: A Revisited Approach." Geneva Risk and Insurance Review 37:223-57.

Chang, Chun-Ping, Chien-Chiang Lee, and Meng-Chi Hsieh. 2011. "Globalization, Real Output, and Multiple Structural Breaks.” Global Economic Review 40 (4): 421-44.

Chase-Dunn, Christopher. 1999. "Globalization: A World-Systems Perspective." Journal of World-Svstems Research 5 (2): 186-215.

Cizre, Ümit, and Erinç Yeldan. 2005. "The Turkish Encounter with Neo-liberalism: Economics and Politics in the 2000/2001 Crises." Review of International Political Economv 12 (3): 387-408.

Demir, Ömer, Mustafa Acar, and Metin Toprak. 2004. "Anatolian Tigers or Islamic Capital: Prospects and Challenges.” Middle Eastern Studies 40 (6): 166-88.

DiMaggio, Paul J., and Walter W. Powell. 1983. "The Iron Cage Revisited: Institutional Isomorphism and Collective Rationality in Organizational Fields." American Sociological Review 48:147-60.

Djelic, Marie-Laure, and Kerstin Sahlin-Andersson. 2006. Transnational Governance: Institutional Dynamics of Regulation. Cambridge: Cambridge University Press.

Dobrev, Stanislav D., Salih Zeki Özdemir, and Albert C. Teo. 2006. "The Ecological Interdependence of Emergent and Established Organizational Populations: Legitimacy Transfer, Violation by Comparison, and Unstable Identities." Organization Science 17 (5): $577-97$.

Dorian, Jones. 1997. "Higher Education in Turkey." Times Higher Education Supplement, no. $1277: 10$.

Dreher, Axel. 2006. "Does Globalization Affect Growth? Empirical Evidence from a New Index.” Applied Economics 38 (10): 1091-1110.

Eckhardt, Jonathan T., and Scott A. Shane. 2003. "Opportunities and Entrepreneurship." Journal of Management 29 (3): 333-49.

Esteban, Joan-Maria, and Debraj Ray. 1994. "On the Measurement of Polarization." Econometrica 62 (4): 819-51.

Fiss, Peer C., Mark T. Kennedy, and Gerald F. Davis. 2012. "How Golden Parachutes Unfolded: Diffusion and Variation of a Controversial Practice." Organization Science 23 (4): 1077-99.

Gamson, William A. 1992. Talking Politics. New York: Cambridge University Press.

Geertz, Clifford. 1998. "The World in Pieces: Culture and Politics at the End of the Century." Focaal: Tijdschift voor Antropologie 32:91-117.

Giddens, Anthony. 1990. The Consequence of Modernity. Stanford, Calif.: Stanford University Press. 
Gökaçtı, Mehmet Ali. 2005. Türkiye’de Din Eğitimi ve Imam Hatipler. Istanbul: İletişim Yayınları.

Göle, Nilüfer. 2000. "Snapshots of Islamic Modernities.” Daedalus 129 (1): 91-117.

Guillén, Mauro F. 2001. "Is Globalization Civilizing, Destructive or Feeble? A Critique of Five Key Debates in the Social Science Literature." Annual Review of Sociology 27:235-60.

Güven, İsmail. 2005. "The Impact of Political Islam on Education: The Revitalization of Islamic Education in the Turkish Educational Setting." International Journal of Educational Development 25 (3): 193-208.

Hamilton, James D. 1994. Time Series Analysis. Princeton, N.J.: Princeton University Press.

Hannan, Michael T. 2010. "Partiality of Memberships in Categories and Audiences.” $\underline{A n-}$ nual Review of Sociology 36:159-81.

Hannan, Michael T., and John Freeman. 1987. "The Ecology of Organizational Founding: American Labor Unions, 1836-1985.” American Journal of Sociology 92 (4): 910-43.

- 1989. Organizational Ecology. Cambridge, Mass.: Harvard University Press.

Hannan, Michael T., László Pólos, and Glenn R. Carroll. 2007. Logics of Organization Theory: Audiences, Codes, and Ecologies. Princeton, N.J.: Princeton University Press.

Harrison, Glenn W., Thomas F. Rutherford, and David G. Tarr. 1993. "Trade Reform in the Partially Liberalized Economy of Turkey." World Bank Economic Review 7 (2): $191-218$.

Harvey, David. 1989. The Condition of Postmodernity: An Inquiry into the Origins of Cultural Change. Oxford: Blackwell.

Hasan, Noorhaidi. 2009. "Islamizing Formal Education: Integrated Islamic School and New Trends in Formal Education Institution in Indonesia." RSIS working paper no. 172. S. Rajaratnam School of International Studies, Nanyang Technological University.

Hasenfeld, Yeheskel, and Benjamin Gidron. 2005. "Understanding Multi-purpose Hybrid Voluntary Organizations: The Contributions of Theories on Civil Society, Social Movements and Non-profit Organizations." Journal of Civil Society 1 (2): 97-112.

Haveman, Heather A., and Hayagreeva Rao. 1997. "Structuring a Theory of Moral Sentiments: Institutional and Organizational Coevolution in the Early Thrift Industry." American Journal of Sociology 102:1606-51.

- 2006. "Hybrid Forms and the Evolution of Thrifts." American Behavioral Science 49 (7): 984-96.

Haveman, Heather A., Hayagreeva Rao, and Srikanth Paruchuri. 2007. "The Winds of Change: The Progressive Movement and the Bureaucratization of Thrift." American Sociological Review 72:117-42.

Held, David. 1998. "Democracy and Globalization.” Pp. 11-27 in Re-imagining Political Community Studies in Cosmopolitan Democracy, edited by D. Archibugi, D. Held, and M. Köhler. Stanford, Calif.: Stanford University Press.

Held, David, Anthony McGrew, David Goldblatt, and Jonathan Perraton. 1999. Global Transformations. Stanford, Calif.: Stanford University Press.

Helvacioglu, Banu. 2000. "Globalization in the Neighborhood: From the Nation State to Bilkent Center.” International Sociologv 15 (2): 326-42.

Heper, Metin, and Aylin Güney. 2000. "The Military and the Consolidation of Democracy: The Recent Turkish Experience." Journal of Armed Forces and Societv 26 (4): 635-58.

Hsu, Greta, Michael T. Hannan, and Özgecan Koçak. 2009. "Multiple Category Membership in Markets: An Integrative Theory and Two Empirical Tests." American Sociological Review 74 (1): 150-69.

Ingram, Paul, and Hayagreeva Rao. 2004. "Store Wars: The Enactment and Repeal of Anti-Chain-Store Legislation in America." American Journal of Sociology 110 (2):446-87. 


\section{American Journal of Sociology}

Kaya, Ibrahim. 2004. Social Theory and Later Modernities: The Turkish Experience. Liverpool: Liverpool University Press.

Kennedy, Mark Thomas, and Peer Christian Fiss. 2009. "Institutionalization, Framing, and Diffusion: The Logic of TQM Adoption and Implementation Decisions among US Hospitals." Academv of Management Journal 52 (5): 897-918.

Kern, Thomas. 2010. "Translating Global Values into National Contexts: The Rise of Environmentalism in South Korea." International Sociologv 25 (6): 869-96.

Keyman, E. Fuat. 2007. "Modernity, Secularism and Islam: The Case of Turkey." Theorv, Culture and Societv 24 (2): 215-34.

Keyman, E. Fuat, and Berrin Koyuncu. 2005. "Globalization, Alternative Modernities and the Political Economy of Turkey." Review of International Political Economv 12 (1): 105-29.

Kirzner, Israel M. 1997. "Entrepreneurial Discovery and the Competitive Market Process: An Austrian Approach.” Journal of Economic Literature 35:60-85.

Kovács, Balázs, and Michael T. Hannan. 2010. "The Consequences of Category Spanning Depend on Contrast." Research in the Sociology of Organizations 31:593-99.

Kuru, Ahmet T. 2003. "Fethullah Gülen's Search for a Middle Way between Modernity and Muslim Tradition." Pp. 115-30 in Turkish Islam and the Secular State: The Gülen Movement, edited by M. Hakan Yavuz and John L. Esposito. Syracuse, N.Y.: Syracuse University Press.

Kurzman, Charles. 1998. "Organizational Opportunity and Social Movement Mobilization: A Comparative Analysis of Four Religious Movements.” Mobilization 3 (1): $23-$ 49.

Lamont, Michèle, and Virág Molnar. 2002. "The Study of Boundaries in the Social Sciences." Annual Review of Sociology 28:167-95.

Landau, Jacob M. 1997. "Turkey between Secularism and Islamism." Jerusalem Letter/ Viewpoints, no. 352 .

Liang, Kung-Yee, and Scott L. Zeger. 1986. "Longitudinal Data Analysis Using Generalized Linear Models." Biometrika 73 (1): 13-22.

Marquis, Christopher, and Julie Battilana. 2009. "Acting Globally but Thinking Locally? The Enduring Influence of Local Communities on Organizations." Research in Organizational Behavior 29:283-302.

Marquis, Christopher, and Zhi Huang. 2009. "The Contingent Nature of Public Policy and the Growth of US Commercial Banking." Academv of Management Journal 52 (6): $1222-46$

Marquis, Christopher, and Michael Lounsbury. 2007. "Vive La Resistance: Competing Logics and the Consolidation of the U.S. Community Banking." Academv of Management Journal 50 (4): 799-820.

McCullagh, Peter, and John A. Nelder. 1989. Generalized Linear Models. Boca Raton, Fla.: CRC Press.

McGrew, Anthony. 1997. "Democracy beyond Borders." Pp. 231-66 in The Transformation of Democracy? Globalization and Territorial Democracy, edited by Anthony McGrew. Cambridge: Polity.

McKendrick, David G., Jonathan Jaffee, Glenn R. Carroll, and Olga M. Khessina. 2003. "In the Bud? Disk Array Producers as a (Possibly) Emergent Organizational Form." Administrative Science Ouarterlv 48 (1): 60-93.

Meyer, David S., and Suzanne Staggenborg. 1996. "Movements, Countermovements, and the Structure of Political Opportunity." American Journal of Sociologv 101 (6): 162860.

Meyer, John W. 2000. "Globalization: Sources and Effects on National States and Societies." International Sociology 15 (2): 233-48.

Meyer, John W., John Boli, George M. Thomas, and Francisco O. Ramirez. 1997. "World Society and the Nation-State." American Journal of Sociologv 103 (1): 144-81. 
Meyer, John W., Patricia Bromley, and Francisco O. Ramirez. 2010. "Human Rights in Social Science Textbooks: Cross-National Analysis, 1970-2008." Sociology of Education 83 (4): 111-34.

Meyer, John W., and Michael T. Hannan. 1979. "National Development in a Changing World System: An Overview." Pp. 3-16 in National Development and the World System: Educational, Economic, and Political Change, 1950-1970, edited by John W. Meyer and Michael T. Hannan. Chicago: University of Chicago Press.

Minkoff, Debra C. 1994. "From Service Provision to Institutional Advocacy: The Shifting Legitimacy of Organizational Forms.” Social Forces 72 (4): 943-69.

. 2002. "The Emergence of Hybrid Organizational Forms: Combining IdentityBased Service Provision and Political Action." Non-profit and Voluntary Sector Ouarterly 31 (3): 377-401.

Nielsen, François, and Michael T. Hannan. 1977. "The Expansion of National Educational Systems: Tests of a Population Ecology Model.” American Sociological Review 42 (3): 479-90.

Oliver, Amalya L., and Kathleen Montgomery. 2000. "Creating a Hybrid Organizational Form from Parental Blueprints: The Emergence and Evolution of Knowledge Firms." Human Relations 53 (1): 33-56.

Oliver, Christine. 1991. "Strategic Responses to Institutional Processes." Academy of Management Review 16 (1): 145-79.

Olzak, Susan, and Elizabeth West. 1991. "Ethnic Conflict and the Rise and Fall of Ethnic Newspapers." American Sociological Review 56:458-74.

Önis, Ziya. 1997. "The Political Economy of Islamic Resurgence in Turkey: The Rise of the Welfare Party in Perspective." Third World Ouarterly 18 (4): 743-66.

Özbudun, Ergun, and E. Fuat Keyman. 2002. "Cultural Globalization in Turkey." Pp. 296-321 in Many Globalizations, edited by P. L. Berger and S. P. Huntington. Oxford: Oxford University Press.

Özgür, İren. 2012. Islamic Schools in Modern Turkey: Faith, Politics, and Education. Cambridge: Cambridge University Press.

Pak, Soon-Yong. 2004. "Cultural Politics and Vocational Religious Education: The Case of Turkey." Comparative Education 40 (3): 321-41.

Pekarskiene, Irena, and Rozita Susniene. 2011. "An Assessment of the Level of Globalization in the Baltic States." Engineering Economics 22 (1): 58-68.

Potrafke, Niklas. 2010. "Labor Market Deregulation and Globalization: Empirical Evidence from OECD Countries.” Review of World Economics 146 (3): 545-71.

Rabasa, Angel, and F. Stephen Larrabee. 2008. The Rise of Political Islam in Turkey. Santa Monica, Calif.: Rand Corporation.

Rao, Hayagreeva, Philippe Monin, and Rodolphe Durand. 2005. "Border Crossing: Bricolage and the Erosion of Categorical Boundaries in French Gastronomy." American Sociological Review 70 (6): 968-91.

Rao, Hayagreeva, Lori Qingyuan Yue, and Paul Ingram. 2011. "Laws of Attraction: Regulatory Arbitrage in the Face of Activism in Right-to-Work States." American Sociological Review 76 (3): 365-85.

Ritzer, George. 1993. The McDonaldization of Society. London: Pine Forge Press.

Robertson, Roland. 1992. Globalization: Social Theory and Global Culture. London: Sage.

Robertson, Roland, and Habib Haque Khonder. 1998. "Discourses of Globalization." International Sociology 13 (1): 25-40.

Saito, Hiro. 2011. "Cosmopolitan Nation-Building: The Institutional Contradiction and Politics of Postwar Japanese Education." Social Science Japan Journal 14 (2): 125-44.

Sakallığlu, Ümit Cizre. 1996. "Parameters and Strategies of Islam-State Interaction in Republican Turkey." International Journal of Middle East Studies 28 (2): 231-51.

Salt, Jeremy. 1995. "Nationalism and the Rise of Muslim Sentiment in Turkey." Middle Eastern Studies 31 (1): 13-27. 


\section{American Journal of Sociology}

Sassen, Saskia. 1991. The Global City: New York, London, Tokyo. Princeton, N.J.: Princeton University Press.

Schneiberg, Marc. 2007. "What's on the Path? Path Dependence, Organizational Diversity and the Problem of Institutional Change in the U.S. Economy, 1900-1950." Socioeconomic Review 5 (1): 47-80.

Schneiberg, Marc, and Elizabeth S. Clemens. 2006. "The Typical Tools for the Job: Research Strategies in Institutional Analysis." Sociological Theorv 24 (3): 195-227.

Schneiberg, Marc, Marissa King, and Thomas Smith. 2008. "Social Movements and Organizational Form: Cooperative Alternatives to Corporations in the American Insurance, Dairy and Grain Industries." American Sociological Review 73:635-67.

Schneiberg, Marc, and Michael Lounsbury. 2008. "Social Movements and Institutional Analysis." Pp. 648-70 in Handbook of Organizational Institutionalism, edited by R. Greenwood, C. Oliver, K. Sahlin-Andersson, and R. Suddaby. London: Sage.

Scott, W. Richard. 2008. "Approaching Adulthood: The Maturing of Institutional Theory." Theorv and Societv 37:427-42.

Segrado, Chiara. 2005. "Islamic Microfinance and Socially Responsible Investments." MEDA Project. University of Torino.

Sezer, Duygu B. 1993. State and Society in Turkey: Continuity and Change? Santa Monica, Calif.: Rand Corporation.

Shane, Scott, and Sankaran Venkataraman. 2000. "The Promise of Entrepreneurship as a Field of Research." Academy of Management Review 25 (1): 217-26.

Simons, Tal, and Paul Ingram. 2004. "An Ecology of Ideology: Theory and Evidence from Four Populations." Industrial and Corporate Change 13 (1): 33-59.

Sine, Wesley D., and Brandon H. Lee. 2009. "Tilting at Windmills? The Environmental Movement and the Emergence of the US Wind Energy Sector." Administrative Science Quarterly 54 (1): 123-55.

Somel, Selçuk Akşin. 2001. The Modernization of Public Education in the Ottoman Empire, 1839-1908: Islamization, Autocracy, and Discipline. Boston: Brill.

Tilly, Charles. 1978. From Mobilization to Revolution. New York: McGraw-Hill.

Wezel, Filippo Carlo. 2005. "Location Dependence and Industry Evolution: Founding Rates in the United Kingdom Motorcycle Industry, 1895-1993." Organization Studies 26 (5): 729-54.

Yavuz, M. Hakan. 1997. "Political Islam and the Welfare (Refah) Party in Turkey." Comparative Politics 30 (1): 63-82.

Zürcher, Eric J. 2004. Turkey: A Modern History. London: IB Tauris. 